\title{
An update of the Worldwide Integrated Assessment (WIA) on systemic insecticides. Part 3: alternatives to systemic insecticides
}

\author{
Lorenzo Furlan ${ }^{1} \cdot$ Alberto Pozzebon ${ }^{2} \cdot$ Carlo Duso $^{2}$ - Noa Simon-Delso ${ }^{3}$. Francisco Sánchez-Bayo ${ }^{4}$. \\ Patrice A. Marchand ${ }^{5} \cdot{\text { Filippo } \text { Codato }^{6} \cdot \text { Maarten Bijleveld van Lexmond }^{7} \cdot \text { Jean-Marc Bonmatin }}^{8}$ (i)
}

Received: 8 August 2017 / Accepted: 13 December 2017 / Published online: 25 February 2018

(C) The Author(s) 2018. This article is an open access publication

\begin{abstract}
Over-reliance on pesticides for pest control is inflicting serious damage to the environmental services that underpin agricultural productivity. The widespread use of systemic insecticides, neonicotinoids, and the phenylpyrazole fipronil in particular is assessed here in terms of their actual use in pest management, effects on crop yields, and the development of pest resistance to these compounds in many crops after two decades of usage. Resistance can only be overcome in the longterm by implementing methods that are not exclusively based on synthetic pesticides. A diverse range of pest management tactics is already available, all of which can achieve efficient pest control below the economic injury level while maintaining the productivity of the crops. A novel insurance method against crop failure is shown here as an example of alternative methods that can protect farmer's crops and their livelihoods without having to use insecticides. Finally, some concluding remarks about the need for a new framework for a truly sustainable agriculture that relies mainly on natural ecosystem services instead of chemicals are included; this reinforcing the previous WIA conclusions (van der Sluijs et al. Environ Sci Pollut Res 22:148-154, 2015).
\end{abstract}

Keywords Systemic insecticides $\cdot$ Neonicotinoids $\cdot$ Fipronil $\cdot$ Mutual funds $\cdot$ Insurance cover $\cdot$ Pest control $\cdot$ Resistance $\cdot$ Biological control $\cdot$ IPM $\cdot$ Review

Responsible editor: Philippe Garrigues

Jean-Marc Bonmatin

bonmatin@cnrs-orleans.fr

1 Veneto Agricoltura, Legnaro (PD), Italy

2 Department of Agronomy, Food, Natural Resources, Animals and Environment, University of Padova, Viale dell'Università 16, 35020 Legnaro (PD), Italy

3 Beekeeping Research and Information Centre, Louvain la Neuve, Belgium

4 School of Life and Environmental Sciences, The University of Sydney, 1 Central Avenue, Eveleigh, NSW 2015, Australia

5 Institut Technique de l'Agriculture Biologique (ITAB), 149 Rue de Bercy, 75595 Paris, France

6 Condifesa Veneto, Associazione regionale dei ccnsorzi di difesa del Veneto, Via F.S. Orologio 6, 35129 Padova (PD), Italy

7 Task Force on Systemic Pesticides, 46 Pertuis-du-Sault, 2000 Neuchâtel, Switzerland

8 Centre de Biophysique Moléculaire, Centre National de la Recherche Scientifique (CNRS), Rue Charles Sadron, 45071 Orléans, France

\section{Introduction}

After the publication of the World Integrated Assessment (WIA) on Systemic Insecticides (Bijleveld van Lexmond et al. 2015; van der Sluijs et al. 2015), some new research about neonicotinoids and fipronil have been made available. In this update, we have endeavored to collect all new information that has been published since 2014 onwards on the same topics covered by the WIA. The first review paper of the updated WIA (Giorio et al. 2017, this special issue) deals with the mode of action of neonicotinoids and fipronil, their metabolism, synergies with other pesticides or stressors, degradation products, and the contamination of the environment. The second updated WIA review covers the lethal and sublethal effects of neonicotinoids and fipronil on organisms, from aquatic and terrestrial invertebrates to vertebrates, and their impacts on ecosystems (Pisa et al. 2017, this special issue). The present review focuses on alternatives to the uses of these systemic insecticides for annual and perennial crops. Pest resistance to neonicotinoids and fipronil is also reviewed. 
The prophylactic use of neonicotinoids and fipronil in crop protection is contrasted with integrated pest management (IPM) for controlling pests (Barzman et al. 2015; Furlan et al. 2016; Stenberg2017). We have divided this task in accordance with two main types of crops: (a) annual crops and (b) perennials (e.g., orchards and vineyards). A new Mutual Funds (MF) insurance approach that covers risk from IPM implementation, applied at a large scale for maize in Italy, showed that it is possible to bring numerous advantages for farmers and ecosystems when implementing IPM.

Abundant information is available about the negative impacts of neonicotinoids and fipronil on the environment, which are due to the sum of (1) their extreme toxicity to invertebrates (Pisa et al. 2015, 2017); (2) their high toxicity to vertebrates (Gibbons et al. 2015; Pisa et al. 2017); (3) their high persistence in soils and the contamination of surface water, both of which impact ecosystems and the services they provide (Bonmatin et al. 2015; Chagnon et al. 2015; Giorio et al. 2017; Pisa et al. 2017); and (4) their large-scale and widespread usage in all kinds of crops, even in nonagricultural settings (Simon-Delso et al. 2015; Douglas and Tooker 2015). However, there is a great deal of reluctance to reduce or phase out these insecticides because of fears that crops may experience yield losses and hurt farmer's economies. Accurate information on the efficacy of prophylactic usage and other applications of these systemic insecticides and the environmental damage they cause should help resolve this issue in a rational way. Moreover, a suite of alternative methods already available, in the context of pest resistance to synthetic insecticides, should provide regulators with more sustainable possibilities for pest management of crops.

\section{Neonicotinoids and fipronil in agriculture}

\section{Neonicotinoids and crop yields}

Little information is available about the actual performance of neonicotinoids on crop production. However, concerns that crop yields might decrease significantly after the European moratorium (EU 2013a, b) of three neonicotinoids (clothianidin, imidacloprid, and thiamethoxam) and fipronil have been raised in the media and a few scientific publications (e.g., in Matyjaszczyket al. 2015 for maize and oilseed rape in Poland), although they were not supported by reliable data or statistics.

In Finland, yields of insect-pollinated crops are variable, whereas yields for wind-pollinated crops have been increasing for decades. While analyzing the possible factors related to yield declines for insect-pollinated crops, a significant linear correlation was found between the yield trends in rapeseed and the extent of neonicotinoid seed dressing used in provinces of that country (Hokkanen et al. 2017). In particular, yield declines in turnip rapeseed decreased as the use of neonicotinoid seed dressing increased. At the same time, the availability of honey bee colonies with respect to the growing area of crops benefitting from insect pollination had a linear, significant impact on turnip rapeseed yield trends. Since landscape and numbers of honey bee colonies had not changed during the period of the turnip rapeseed study, the authors of that study indicate that the only factor that could explain this decline in yields was the seed-treatment with neonicotinoids in the past 15 years.

In the UK, Budge et al. (2015) showed that yields of oilseed rape crops are not significantly increased by using imidacloprid in treated seeds. While the authors reported that farmers may get better economic returns some years, as they apply seed coatings which reduced the number of subsequent applications of foliar insecticide sprays, they also revealed a correlation over an 11-year-period between honey bee colony losses and national-scale imidacloprid usage patterns across England and Wales. These findings on oilseed rape yields are consistent with previous reports on the non-usefulness of neonicotinoids in soybean (Seagraves and Lundgren 2012) and wheat crops (Macfadyen et al. 2014).

In regard to maize, the available literature, mainly about studies in Italy, shows that the effect of seed-coated neonicotinoids on grain yield was mainly negligible (Furlan and Kreutzweiser 2015 citing different papers on field trials covering a 15 -year period). This was mainly due to the fact that the majority of pest populations were under the economic injury level.

Other studies have shown that neonicotinoid insecticides can have effects on germination. For instance, Nogueira Soares et al. (2017) co-published with Syngenta that thiamethoxam improves physiological performances of melon and watermelon seeds treated with this neonicotinoid. By contrast, Tamindžić et al. (2016) have shown that three commercial formulations (i.e., Poncho, Gaucho and Cruiser) were harmful and reduced germination of three inbred maize varieties. The most harmful treatment was Gaucho (active ingredient (a.i.) imidacloprid) when compared to Cruiser (a.i. thiamethoxam) and Poncho (a.i. clothianidin, a derivative of thiamethoxam).

Deguines et al. (2014) analyzed a country-wide dataset of the 54 major crops in France produced over the past two decades. They found that the benefits of agricultural intensification decrease with increasing pollinator dependence, to the extent that intensification failed to increase the yield of pollinator-dependent crops and decreased the stability of their yield over time. The authors concluded that benefits from agricultural intensification may be offset by reductions in pollination services and support the need for an ecological intensification (reviewed by Kovács-Hostyánszki et al. 2017) of agriculture through optimization of ecosystem services. In other words, the prophylactic use of systemic insecticides, which impacts on both managed and wild pollinators (Pisa et al. 2015, 2017), is opposed to yield increases for pollinator dependent crops. 


\section{Alternatives to systemic insecticides in agriculture}

\section{Annual crops}

The use of systemic insecticides against key pests of annual crops The use of neonicotinoids or fipronil against the main pests of annual crops was previously described in Furlan and Kreutzweiser (2015) and Simon-Delso et al. (2015). It was stressed that the main use of these systemic insecticides is prophylactic, for instance by means of seed coating techniques, and that this systematic approach is contrary to IPM principles (Furlan et al. 2016).

\section{Alternative methods for pest control in annual crops Some} new IPM strategies that reliably limit the need for treatments involving neonicotinoids were also described in Furlan and Kreutzweiser (2015). The need for more data on the factors driving the risk of soil pest damage to maize and other susceptible crops, mainly to wireworm attacks, was emphasized in order to improve both the practical approach for farmers and the setup of specific MF to support IPM implementation. In practice, pest level evaluation is often not done mostly because of a lack of non-time-consuming and low cost methods (essential for low revenue crops) and insurance to cover for the risk of mistakes in pest population estimations. Some interesting recently published papers contribute to this issue: after a 29-year long-term study in Italy, the strongest factors increasing the risk of wireworm damage have been isolated, making now possible low-cost and reliable predictions to meet crop protection needs (Furlan et al. 2017).

A univariate analysis in the risk assessment was applied to identify the main factors that influence the occurrence of damage. Then, a multifactorial model was applied using the significant factors identified in the previous step. This model allows the strongest factors to be highlighted and to analyze how the main factors together influence the damage risk. The strongest factors were Agriotes brevis as the prevalent damaging species; organic matter content $>5 \%$; rotation, including meadows and double crops; poor soil drainage; and A. sordidus as the prevalent damaging species. Also, the surrounding landscape with prevalent meadows was an important risk factor, confirming previous findings by other authors (Blackshaw and Hicks 2013; Benefer et al. 2012; Hermann et al. 2013; Saussure et al. 2015). The multifactorial model also showed how the simultaneous occurrence of two or more of the aforementioned risk factors can conspicuously increase the risk of wireworm damage to the maize crop, while the probability of damage for a field with no risk factors is always low $(<1 \%)$. These results make it possible to prepare risk maps for any country identifying low-risk and high-risk areas.

This information may be used to implement IPM and to tackle soil pests attacking maize in many European regions (Furlan et al. 2016) and beyond, which may lead to a considerable reduction in the use of soil insecticides and the immediate containment of the environmental impact of agriculture with no negative repercussions on farmers' income. This can be achieved by implementing two phases: (i) "areawide" risk assessment, including click-beetle population monitoring with pheromone traps (Furlan and Kreutzweiser 2015) and (ii) complementary field monitoring where risk assessment has identified the presence of risk factors (Furlan et al. 2016). When a harmful population is found, wirewormactivity-predicting models based on soil humidity and temperature may be useful to assess if the damage is really being done by larvae (Jung et al. 2014; Milosavljević et al. 2016).

The results of this work enable mapping of each cultivated region and high-risk areas to be pinpointed. Mapping the risk factors found in this survey, and that of Saussure et al. (2015) outside Italy, may allow us to prove that the cost-benefit of past soil-insecticide use was extremely negative. The first layer of the map includes the main soil characteristics (organic-matter content, texture, $\mathrm{pH}$ ); the second includes the key agronomic characteristics (rotation, drainage); and the third the available entomological information, such as click-beetle population levels for the main Agriotes species, or wireworm presence/ density assessed with bait traps over the years. A fourth layer reproduces the effects that occur when existing risk factors interact. This system enables areas with different risk levels to be highlighted. Each wireworm-risk category (e.g., low, medium, or high, based on the presence of one or more risk factors) will have its own IPM strategy, e.g., assessing wireworm density in high-risk areas or opting not to treat and not to continue monitoring in low-risk areas. Where risk factors are present, a precise procedure to spot land with an economic wireworm population has been described. In this way, control strategies will be implemented only when and where economic thresholds for maize are exceeded, and then it will be possible to avoid expensive soil insecticide use. Note that the risk factors causing high wireworm populations in maize are the same as those in non-maize crops. Therefore, they can be used to implement IPM in all arable crops, with possible adaptations.

Choosing fields with no risk factors may reduce the damage risk for all crops, including sensitive vegetable crops. Assessing the risk of wireworm damage affords a solid basis for estimating the amount of farmland that can be left untreated each season, without any risk of yield reduction. In Italy, implementing IPM is likely to result in a maximum of about $4 \%$ of maize-cultivated land being treated with soil insecticides or by using insecticidecoated seeds (Furlan et al. 2017). This means that $96 \%$ of these fields will not need any insecticide treatment. Precise IPM thresholds for soil pests in maize could be set everywhere. For instance, in no-risk areas, soil insecticides or insecticide-coated seeds may need to be used on no more than $1 \%$ of maizecultivated land. In areas where organic matter content is over $5 \%$, soil insecticides could be used on about $20 \%$ of maizecultivated land if the prevalent species is A. sordidus. For large 
areas with scattered-risk situations, IPM thresholds will be a balanced mean of the damage risk caused by various risk factors and the surface area of cultivated land where each risk factor occurs. This could be immediately applied to areas harboring the species studied therein and to other areas shortly afterwards. In fact, local checks and adaptations should be assessed in regions where other species and/or conspicuous climatic differences occur, but the aforementioned IPM approach should be used since it is likely that the same main risk factors would play a key role. This would allow IPM to be extended wherever the Agriotes species studied in this work are widespread, and probably also to wherever other Elateridae species occur, once accurate comparisons have been made.

\section{MF insurance cover}

A low-cost IPM approach for low-risk pests based on risk factors and limited direct monitoring of fields makes it important that farmers get an appropriate compensation for the few fields that suffer from pest soil damage which differ from IPM predictions due to natural variability of the phenomena. In this case, risk insurance coverage may be extremely useful. Insurance cover/MF may be taken out privately by associated farmers, or with the support of EU regulations (Reg. 1305/2013/EU). With risks below 1\%, a few Euros per hectare (about ten times less than soil-insecticide costs) would be enough to pay for damaged fields (Ferrari et al. 2015), including those damaged despite having been treated with soil insecticides, the likelihood of which is high (Saussure et al. 2015). MFs are instruments managed by collectives of farmers aimed at creating compensation through an interregional distribution of risks. They are non-profitable and have transparent rules. Compensation is commensurate with the financial resources of the Fund. The Fund stock is increased by savings in forecast costs. They cover risks that private insurance companies currently do not (e.g., climatic adversities such as flooding, and damage by wild animals and pests, just before and after the emergence of arable crops). The Italian Case study for implementation described here covered large-scale areas ( $>47,000 \mathrm{ha}$ ) in two regions of high agricultural importance, Veneto and Friuli-Venezia Giulia.

In the above-cited regions, a long-term research and survey (>29 years) demonstrated that economic damage risk by soil pests is less than 4\%, and that a reliable IPM procedure is available to spot which fields really need protection from pests. As described above, the absence of risk factors greatly decreases the chance of economic damage and makes the application of soil insecticides in most fields useless. Where risk factors are present, an appropriate practice is to assess wireworm populations with bait traps and to introduce control strategies only when and where economic thresholds for maize are exceeded. This is clearly opposite to the systematic and prophylactic uses of systemic insecticides. Insurance covers also the risk of mistakes in IPM implementation, including any underestimation in the size of the area with wireworm economic populations (Furlan et al. 2015). Based on this risk assessment, a specific Maize Mutual Fund was set up. Its main features are summarized in Table 1. In essence, farmers should use pesticides only when they are really needed, based on IPM procedures suggested by the Annual Crops Bulletin (accessible at http://www.venetoagricoltura.org/ subindex.php?IDSX=120), while getting insurance cover for mistakes and unexpected damages.

The practical implementation of Maize MF in 2015-2016 resulted in the following economic and management effects: 47.558 ha were covered by the Maize MF on average over the 2 years; the cost was $3.3 € /$ ha (about one tenth the cost for a soil insecticide); total revenue to cover damage by wireworms, western corn rootworm, wild fauna, and other minor pitfalls was $160.335 €$, while total damage paid was $83.863 €(\sim$ $52 \%$ ). Therefore, there was a very significant increase of the MF stock for following years.

The comparison between the prophylactic approach with soil insecticides to protect maize seeds/young plants at sowing and IPM approaches based on MF implementation are showed in Table 2. Costs of IPM implementation for farmers and of running MF are detailed below as farmer's cost and institution's cost:

Table 1 Main features of the Mutual Fund (MF) strategy for maize in Italy.

\begin{tabular}{|c|c|}
\hline Participants & Members of the farmer consortia \\
\hline Obligations & $\begin{array}{l}\text { - Contract to be signed within } 7 \text { days after sowing } \\
\text { - Implementation of good cultivation practices } \\
\text { - Implementation of Directive 128/2009/EC } \\
\text { - Implementation of suggestions in the "Annual Crops } \\
\text { Bulletin" }\end{array}$ \\
\hline Risks covered & $\begin{array}{l}\text { - Insufficient plant density (stand) due to adverse weather } \\
\text { conditions (i.e., drought, flooding, freezing cold) } \\
\text { - Insufficient plant density (stand) due to soil pests } \\
\text { (e.g., wireworms, black cutworms) } \\
\text { - Insufficient plant density (stand) due to diseases such as } \\
\text { Fusarium spp. (rotten roots, seedlings) } \\
\text { - Diabrotica (WCR) damage } \\
\text { - Loss of production caused by wild fauna }\end{array}$ \\
\hline Cost & $\begin{array}{l}€ 3-5 / \text { ha all inclusive (flooding, excessive rain, freezing } \\
\text { cold, drought, pest risk, diseases, and wild fauna) }\end{array}$ \\
\hline Compensation & $\begin{array}{l}\text { - Changing crop for WCR damage (up to } € 1000 / \mathrm{ha} \text { ) } \\
\text { - Up to } € 500 / \text { ha including the cost of: } \\
\circ \text { Re-sowing, if stand below } 4 \mathrm{PLS} / \mathrm{m}^{2} \text { (up to } € 250 / \mathrm{ha} \text { ) } \\
\text { oYield reduction because of sowing delay (up to } \\
€ 250 / \text { ha) }\end{array}$ \\
\hline
\end{tabular}

$P L S$ pure life seed 


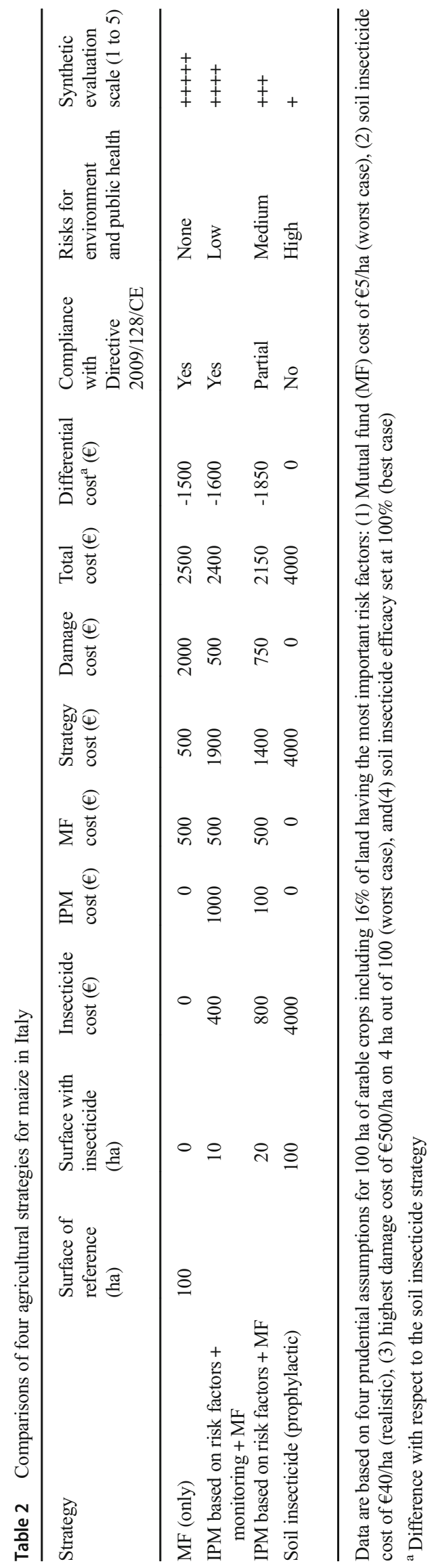

1. Farmers' costs of IPM implementation are given in the fifth column from left in Table 2. The obligation for farmers is to follow IPM suggestions of the Annual Crops Bulletin for an actual implementation of IPM principles. If just an evaluation of risk factors presence is done (see the fourth row from above), only 4-5 hours of a technician are needed (about $100 € / 100$ ha). If a full IPM implementation is considered (see the third row from above), the estimated total cost is $1000 € / 100$ ha. It corresponds to 16 ha at risk, as assuming they are monitored with bait traps (Furlan 2014). It includes $2 \mathrm{~h} / \mathrm{ha}$ to do the monitoring - about $40 € /$ ha with a subtotal cost of $640 €$, $60 €$ for materials, $100 €$ for travel costs and overheads, and about $200 €$ that might be needed for an accurate risk analysis with mapping of the cultivated fields and further insight. Note that in Europe, these costs should not be considered as additional costs since the compliance with IPM principles and the connection with IPM Bulletins are compulsory for all the crops in all Member States in Europe.

2. Institution's costs are considered in the sixth column from left in Table 2. They correspond to a total MF cost of 5 $€ /$ ha. This includes both $4 € /$ ha of pure premium to cover the actual damage risk (a prudent figure higher than precise estimation done), and $1 € /$ ha for specific administrative costs (including fixed costs) and for the costs of damage assessments by experts in fields where farmers ask to visit. Over the 4 years of practical implementation of MF, this latter cost per year ranged between 5 and $15 \%$ of the revenue from farmers to cover damage by pitfalls. More precisely, this maximum cost was $0.6 € /$ ha but, to follow a prudential approach, we overestimated this cost at $1 € /$ ha in Table 2.

Because of this generally low risk level, the crop insurance program (MF to protect maize at the early stages) proved to be more convenient than insecticide protection on large scale. Growers may purchase MF cover instead of soil insecticides, to provide financial compensation when yield losses can be attributed to pests or adverse weather conditions. In fact, the total cost of damage to maize (e.g., need for re-sowing and yield loss due to delayed sowing or reduced stand) plus the MF cost was much lower than the total cost of the soil insecticide treatments of most fields as the result of prophylactic protection approach (Table 2), even when all the fields are left untreated.

In the two intermediate IPM scenarios of Table 2, the assumptions were (1) a little bit larger land than that presenting risk factors is being treated, including all the border line cases, to minimize the risk of unpredicted damage; (2) since the efficiency of soil insecticide is set at $100 \%$ (an optimistic estimate), by enlarging the treated land the probability of finding 
a field with an economic damage is very low. In the practical application of these two IPM scenarios, economic damages observed in north-east Italy were $<0.1 \%$, which is really negligible. However, to make the exercise extremely severe, we have considered in Table 2 a case worse than the worst case found in practice: a damage of 1 ha out of 100 ha (500€) is considered as unpredicted for IPM based on a risk factor evaluation and a monitoring scenario, whereas an unpredicted damage of 1.5 ha out of $100(750 €)$ was considered for the scenario without monitoring. Nevertheless, a great advantage of applying IPM instead of a prophylactic approach is clear. In addition to economic considerations, MFs avoid the environmental side effects of insecticides on beneficial species, biodiversity, ecosystems, and human health (Furlan et al. 2015; van der Sluijs et al. 2015; Cimino et al. 2017; Pisa et al. 2017).

When risks are low, the insurance approach is thus convenient for farmers and safe for people, biodiversity (including pollinators), the environment, and ecosystems. An insurance approach is much more cost-effective than insecticides since its large-scale and multiannual implementations demonstrated that MF costs are much cheaper for farmers than insecticide use. Obviously, the lower the damage risk is, the more efficient an MF becomes, even without any subsidy. The MF insurance approach can immediately reduce pesticide use and increase farmers' net income by replacing pesticides with a lower cost strategy. Interestingly, MFs allow an increase of IPM application by making farmers more comfortable with IPM procedures, since mistakes in IPM implementation are also covered.

\section{Biological control and natural derived insecticides}

A few papers have recently been published on biological control and natural derived insecticides to control pests in arable crops. One new suggestion is about attract-and-kill strategies using biological tools against soil pests. Brandl et al. (2017) proved this strategy may reduce potato damage by wireworms in organic potato production systems in Lower Saxony, Germany. This strategy is based on the attraction of wireworms towards an artificial carbon dioxide-emitting source, using baker's yeast (Saccharomyces cerevisiae) in combination with Metarhizium brunneum conidia for wireworm infection. This strategy offers the potential to promote biological wireworm control as an alternative to insecticide use by potentially reducing the inoculum compared to an inundate M. brunneum conidia release strategy (Kabaluk et al. 2007). This approach had some practical successful implementations in corn (Kabaluk and Ericsson 2007), like the use of biocidal plants and meals as described in Furlan and Kreutzweiser (2015). Kabaluk (2014) showed that applications of M. brunneum conidia may cause high mortality to adult Agriotes obscurus click beetles in field trials. This was followed by experiments that showed a potential for an attract- and-kill strategy also against Agriotes adults using sex pheromones (Kabaluk et al. 2015).

However, while biocidal plants and meals have become commercial products available for farmers, the setup of ordinary control tools based on the entomopathogens described above requires efforts for the future. A careful cost-benefit analysis is also needed to practically evaluate these alternative tools.

3. Ecological engineering for pest suppression: habitat manipulation for pest management and cultural control

In rice, ecological engineering practices that were first developed in China (Gurr et al. 2012) have been field tested in three countries: China, Thailand, and Vietnam, for multiple years (Gurr et al. 2016; Spangenberg et al. 2015). The results showed that in rice fields grown with flowers on the bunds, insecticide use was reduced by $70 \%$, biological control was increased by $45 \%$, pest populations were decreased by $30 \%$, and yields were increased by $5 \%$. These ecological engineering practices are now widespread in Vietnam (Heong et al. 2014) and China (Lu et al. 2015).

\section{Perennial crops}

\section{The use of neonicotinoids against key pests of perennial crops}

A large number of arthropod pests of temperate fruits (e.g., apple, pear, peach, and cherry) and grapevine have been managed for a long time using synthetic pesticides such as organophosphates and carbamates. Problems associated with their wide use, such as pest resistance, pest resurgence, and outbreaks of secondary pests, as well as concerns about their toxicity towards beneficial invertebrates and mammals, have progressively reduced their availability in many developed countries. Pyrethroids were suggested to replace these pesticides because of their relatively low toxicity towards mammals, but their impact on natural enemies of pests (i.e., predators and parasitoids) with consequent risks of secondary pest outbreaks reduced their appeal for growers involved in IPM in perennial crops (Duso et al. 2014). Additionally, similar risks for aquatic invertebrates as compared to neonicotinoids have been reported (Douglas and Tooker 2016). Chitin synthesis inhibitors were then successfully proposed due to their long persistence activity on target pests and relatively low acute toxicity to mammals. Later, their popularity also declined due to technical (e.g., pest resistance) and environmental issues (risks to aquatic crustaceans) associated with some active ingredients (Castro et al. 2012; Rebach and French 1996). More recently, neonicotinoids were proposed as a category of insecticides characterized by reduced risks to human health. A number of active ingredients showed a high efficacy in the control of sucking insects and other pests, probably because of 
their novel mode of action (MoA) and systemic distribution within plants (Bonmatin et al. 2015 and Giorio et al. 2017).

Aphids are key pests in apple and peach orchards. Preblossom pesticide applications are considered essential to reduce their damage to fruit production, and neonicotinoids proved to be effective in keeping these pests below economic thresholds in fruit orchards (Shearer and Frecon 2002; Beers et al. 2003; Lowery et al. 2005; Brück et al. 2009). In Europe, the use of three active ingredients (i.e., imidacloprid, thiamethoxam, and clothianidin) has been restricted to postblossom applications due to their side effects on honeybees (EU Regulation 485/2013a, b; Pisa et al. 2015, 2017) and further restrictions have been applied in some countries. In some areas, the elimination of a number of broad-spectrum insecticides has been associated with an increase of the rosy apple aphids Dysaphis plantaginea Passerini (Cross et al. 1999; Solomon et al. 2000; Dib et al. 2016), thus prompting the use of neonicotinoids to control them. Neonicotinoids play also a role in the control of the San José scale Diaspidiotus perniciosus Comstock. An advantage of their use is the high systemic activity that allows an effective control of this pest (Buzzetti et al. 2015). In fruit orchards, other pests such as the codling moth, Cydia pomonella (L.), and the oriental fruit moth,Grapholita molesta (Busck), can be controlled with neonicotinoid applications (Jones et al. 2010; Magalhaes and Walgenbach 2011; Yang et al. 2016).

Neonicotinoids were suggested as an alternative tool in the control of medfly (Ceratitis capitata Wiedmann) and South American fruit fly Anastrepha fraterculus (Wiedemann) in peach and nectarine orchards (Raga and Sato 2011; Rahman and Broughton 2016). The results are not always successful, and other control measures, including attract-and-kill techniques, are recommended (Broughton and Rahman 2017).

The spotted wing drosophila, Drosophila suzukii Matsumura, is a serious pest of sweet cherry and other fruit crops. In trials carried out in North America, some neonicotinoids and OPs were effective against this pest (Beers et al. 2011), but in other trials, neonicotinoids seem less effective than other insecticides (Bruck et al. 2011; Shawer et al. 2018). Laboratory experiments suggested that acetamiprid can provide efficient control of $D$. suzukii when applications are performed before egg deposition (Pavlova et al. 2017). Wise et al. (2015) suggested that the use of neonicotinoids is not a good option in post-infestation applications.

Another pest of increasing importance worldwide is the brown marmorated stink bug (BMSB), Halyomorpha halys (Stål) (Hemiptera: Pentatomidae). Invasive in the USA and Europe, BMSB can attack various crops (Leskey et al. 2012). Against this pest, neonicotinoids are considered as an efficient option for its control (Kuhar and Kamminga 2017).

The Asian citrus psyllid Diaphorina citri Kuwayama (Hemiptera: Liviidae) is an economically important pest of citrus worldwide and the vector of the phloem-limited plant pathogen "Candidatus" Liberi bacterasiaticus, the presumptive causal agent of citrus greening disease (or huanglongbing). Neonicotinoid insecticides appear to be the most valuable option for containment of this pest (Ichinose et al. 2010).

Trunk injections of systemic insecticides (e.g., imidacloprid, acephate, dinotefuran) were tested to manage avocado thrips in California (Byrne et al. 2003). Acephate, which has been banned in the EU, was mobilized rapidly and proved to be effective against these thrips, but "unacceptable" pesticide residue contents were detected in fruits. Residues of imidacloprid and dinotefuran were significantly higher in leaves, whereas residues in fruits were below detection limits. The authors suggested that neonicotinoids may be a suitable control option against these pests.

In vineyards, neonicotinoids have been used for management of mealybugs (e.g., Planococcus ficus Signoret) (Wallingford et al. 2015). They were also used against ants that interact by mutualism with mealybugs and coccids in vineyards (Daane et al. 2008). Neonicotinoids, in particular imidacloprid, have been suggested against Daktulosphaira vitifoliae (Fitch) (Herbert et al. 2008), which is becoming aggressive again in some parts of Europe. These insecticides are effectively used to control leafhoppers (e.g., Empoasca vitis Goethe, Erythroneura elegantula Osborn, and Scaphoideus titanus Ball) in the vineyards of Europe and NorthAmerica (Van Timmeren et al. 2011; Žežlina et al. 2013). In the USA, drench application of neonicotinoids has been proposed against mealybugs and leafhoppers (Daane et al. 2008; Van Timmeren et al. 2011).

\section{Alternative methods for pest control in perennial crops}

1. Mating disruption

Mating disruption based on the use of synthetic sexual pheromones (Table 3 ) is an effective control tool against several pests, particularly tortricid moths such as $C$. pomonella, G. molesta, and Lobesia botrana (Den. and Schiff.) (e.g.,Witzgall et al. 2008; Ioriatti and Lucchi 2016). These methods can have some limitations in orchards and vineyards with uneven topography, high pest densities, and more generally in the first years after adoption. Successful control of these pests has been achieved using mating disruption with positive implications for insecticide use reduction and prevention of pesticide resistance (Trimble 1993; Angeli et al. 2007; Bohnenblust et al. 2011; Bosch et al. 2016; Calkins and Faust 2003; Ioriatti et al. 2011). However, recent research in Spain showed that the application of mating disruption in vineyards was associated with an increase of minor pest incidence (Gallardo et al. 2016). Pheromone-based mating disruption has also been developed against grapevine mealybugs with positive results (Walton et al. 2006; Cocco et al. 2014; Sharon et al. 2016). Mating disruption can be induced by substrate-borne vibrations that have been proposed in particular 
Table 3 Summary of the main alternative methods in contrast with extensive, conventional, and intensive agriculture

\begin{tabular}{|c|c|c|c|}
\hline Landscape & Farming methods & Organisms & Others \\
\hline $\begin{array}{l}\text { Patchy (reduced-size } \\
\text { fields) }\end{array}$ & $\begin{array}{l}\text { Mutual funds (insurance } \\
\text { cover) }\end{array}$ & Macro-organisms: & Traps \\
\hline Edge shrubs & Crop rotation & - Parasitoids & Attractants (traps) \\
\hline Edge crops & Resistant variety: & • Predators: & Pheromones (traps) \\
\hline Bund with flowers & - To insects & ○ Vertebrates & Repellants \\
\hline Wet zones (e.g., pond) & - To diseases & $\circ$ Invertebrates & Basic substances \\
\hline Ecological corridors & Late sowing & Micro-organisms: & • Sugars \\
\hline \multirow[t]{9}{*}{ Trees (agroforestry) } & Mixing varieties & - Fungi & - Oils \\
\hline & Tillage & - Bacteria & - Nettle extracts \\
\hline & Intercropping & - Nematodes & Mineral barrier (powders) \\
\hline & Netting & • Viruses & Hot water (plant nursery) \\
\hline & Stale seed bed & & Sex confusion \\
\hline & $\begin{array}{l}\text { Removal of plants bearing } \\
\text { pest }\end{array}$ & & Chemical mediators \\
\hline & Manual pruning & & Plant defense stimulators \\
\hline & Soil cover (e.g., grass) & & Acoustic confusion \\
\hline & & & $\begin{array}{l}\text { Natural-derived } \\
\text { insecticides }\end{array}$ \\
\hline
\end{tabular}

These methods are generally used in combination (without or) with low-risk pesticides for organic farming and IPM practices. These methods contrast with the prophylactic uses of highly toxic pesticides such as neonicotinoids and fipronil. Table adapted from Bonmatin (2016) against some sucking pests that are known to use vibrational signals for communication during mating. Against these pests, vibration-based mating disruption tools have been tested showing potential for extensive applications (Polajnar et al. 2016).

\section{Exclusion netting}

Exclusion netting with insect-proof screens represents another option for pest control (Table 3). Their use has been proposed to protect orchards from moth invasion, with positive effects in aphid population densities reduction (Dib et al. 2010; Sauphanor et al. 2012). More recently, the use of exclusion netting has been suggested for the control of the invasive pests H. halys and D. suzukii (Dobson et al. 2016; Rogers et al. 2016; Leach et al. 2016). These pests are generalist feeders that can repeatedly invade orchards during a season. Exclusion netting should provide a physical obstacle for the colonization of the crops. In addition, nets can be treated chemically, i.e., pyrethroid-impregnated nets. This tool could be used for the control of $H$. halys (Kuhar et al. 2017).

\section{Biological control}

Interest on the release of biocontrol agents to control pests in perennial cropping systems has increased in the last decades (Table 3). Inundative releases of egg parasitoids have been proposed against grape berry moths L. botrana (El Wakeil et al. 2008). However, it should be stressed that biological control not always ensures satisfactory levels of pest suppression and further research is needed to implement biological control strategies of tortricid moths in orchards and vineyards. Natural enemy releases have been proposed for the control of Planococcus ficus (Signoret) in vineyards of the USA, but the full efficacy of these tactics seem to be limited by climatic conditions (Daane et al. 2004).

The control of the woolly apple aphid Eriosoma lanigerum Haussmann represents a successful case of classical biological control by the hymenopteran parasitoid Aphelinus mali (Hald.). Outbreaks of the woolly aphids have often been associated with the negative effect of non-selective pesticides on parasitoid populations. Similar mechanisms can also be related to Cacopsilla pyri L. outbreaks in pear orchards (Solomon et al. 1989; Solomon et al. 2000; Vrancken et al. 2015). The role of predators in controlling peach aphids has been studied extensively (e.g., Pappas and Koveos 2011), but their real potential to keep pest populations under economic threshold levels needs further investigation. Recent research in aphid management showed that an increase in biological control can be indirectly obtained by excluding ants or by providing alternative sugar feeding to ants to reduce the ant-aphid mutualism (Nagy et al. 2013, 2015).

Within microbial pest control agents, a number of entomopathogenic fungi (e.g., Beauveria bassiana Bals. and Paecilomyces fumosoroseus (Wize)) have been evaluated for their activity against $M$. persicae and other aphid species with promising results (Andreev et al. 2012; Lefort et al. 2014; Lee et al. 2015). However, their effects in field conditions have been poorly explored. 
Microbial products based on $C$. pomonella granulovirus (CpGV-M) have been suggested as an alternative in codling moth control (Cross et al. 1999; Beers et al. 2003), but these products have also been involved in resistance (Schmitt et al. 2013). Treatments with the entomophathogenic nematodes Steinernema carpocapsae (Weiser) and Steinernema feltiae Filipjev against overwintering larvae can achieve a good control of the codling moth (Unruh and Lacey 2001; Lacey et al. 2006) but their efficacy is strongly influenced by climatic conditions. Microbial control agents active towards tortricids and other lepidopteran pests include Bacillus thuringiensis Berliner (Cross et al. 1999; Lacey and Shapiro-Ilan 2008; Vassiliou 2011), characterized by its specificity towards Lepidoptera, Diptera, and Coleoptera and reduced risks to human health and the environment. The efficacy of B. thuringiensis can be limited by a number of climatic (e.g., temperature) and agronomic (e.g., differences in larval instar susceptibility, spray coverage, and application rate) factors that should be considered in practice.

\section{Natural-derived insecticides}

Besides biological control and mating disruption, alternatives in sucking pest control in perennial crops are represented by the application of natural-derived insecticides (Table 3). Multiple applications of kaolin, a clay mineral, in apple orchards have been found effective against a number of pests including the green apple aphid Aphis pomi (DeGeer) (Markó et al. 2008). In the same study, severe infestations of the woolly apple aphid have been found in kaolin-treated plots probably because of its negative impact on aphid natural enemies. The use of kaolin has been recently suggested against the grapevine leafhoppers in vineyards (Tacoli et al. 2017). Another option can be the use of fatty acid salts, in particular potassium salts, that have been used with a good efficacy against pear psylla (Souliotis and Moschos 2008).

Botanical insecticides such as those based on Azadirachta indica or natural pyrethrins have been suggested in controlling aphids in orchards and different other pests in vineyards (e.g., Andreev et al. 2012; Cichon et al. 2013; Dercks et al. 2014) but their effects were not always satisfactory. More recently, Annonaceae derivatives have been tested successfully in the laboratory against M. persicae (Ribeiro et al. 2014).

Among natural-derived pesticides, spinosad is a natural mixture of toxins produced by the soil actinomycete Saccharopolyspora spinosa (Mertz and Yao 1990). This compound proved to be effective to control codling moth, grape berry moths, leaf miners, thrips, and dipterans as a recurrent option in organic orchards and vineyards (Reissig 2003; Mota-Sánchez et al. 2008; Vassiliou 2011). However, its use has been associated with negative effects on natural enemies (e.g., predatory arthropods) of importance for fruit orchards and vineyards (Ahmad et al. 2013; Tirello et al. 2013; Duso et al. 2014; Pozzebon et al. 2014; Beers and Schmidt 2014; Malagnoux et al. 2015).

\section{Food-derived biorationals as insect crop protection}

More recently, natural or food-derived insecticides (e.g., vegetable oils), insect repellants (e.g., nettle extract), plant strengtheners (e.g., sucrose, fructose), and trap attractants (e.g., di ammonium phosphate) were approved as basic pest control substances under the European pesticide regulation, with no maximum residue limit (MRL) (Marchand 2015, 2016, 2017).

6. Ecological engineering for pest suppression: habitat manipulation for pest management and cultural control

Agro-ecological practices aimed at enhancing the effectiveness of natural enemies to reduce pest pressure can offer, for some perennial cropping systems, valid alternatives to insecticides in pest management.

In fruit orchards, peach aphid populations can be affected by chemical control measures but also by cultural practices and natural regulation. Fertilization has controversial effects on aphid dynamics and management. In an ad hoc experiment, M. persicae populations increased with a moderate number of treatments but decreased at higher number of treatments. The concentrations of primary and secondary metabolites in the plant were modified by the number of treatments, and this mechanism was suggested to be involved in these contrasting effects (Sauge et al. 2010). Four aphid control strategies, namely intensive, optimised, input-substitution, and integrated control, were compared in France (Penvern et al. 2010). The use of pesticides lowered densities of aphids as well as those of their natural enemies while cultural methods (e.g., ground cover and manual pruning of infested branches) promoted high populations of both arthropod groups. Data were critically discussed to redesign advanced orchard protection strategies that aimed to obtain pest control in the framework of biodiversity conservation. This approach requires local adaptations. For example, in China, the introduction of ground cover based on Trifolium repens L. in peach orchards obtained a significant reduction in the abundances of aphids and G. molesta (>31\%) probably due to the increase of generalist predators $(>115 \%)$ (Wan et al. 2014). The presence of natural enemies in pome fruit orchards can be promoted through habitat management practices such as increasing floral diversity in the agro-ecosystem by using selected trees and grasses (Rieux et al. 1999). The presence of hedgerows may increase the impact of parasitism of the codling moth (Maalouly et al. 2013; Monteiro et al. 2013).

In vineyards, the threats by sucking pests are mainly associated with leafhoppers (e.g., E. vitis and E. elegantula), mealybugs (e.g., P. ficus), thrips (e.g., Drepanothrips reuteri 
Uzel), and spider mites (Panonychus ulmi Koch and Eotetranychus carpini Oudemans). They are generally considered as secondary pests that can be managed by promoting the presence of natural enemies in vineyards (Duso et al. 2012, Walton et al. 2012). This can be achieved by increasing habitat complexity/diversity to provide refuges and alternative hosts and food resources to predators and parasitoids (Costello and Daane 2003; Duso et al. 2004; Ponti et al. 2005; Zanolli and Pavan 2011; Pozzebon et al. 2015a; Wilson et al. 2015) and reducing the use of non-selective pesticides (e.g., Jepsen et al. 2007, Pozzebon et al. 2015b). Biological control strategies against sucking pests can also be enhanced by inoculative or augmentative releases of natural enemies (Duso et al. 1985; Daane et al. 1996; Duso and Vettorazzo 1999; Daane et al. 2008). Irrigation, fertilization, and cultivar choice can be also managed to reduce pest incidence and economic damage (Daane and Williams 2003; Costello 2008; Fornasiero et al. 2012, 2016; Cocco et al. 2015).

\section{Resistance to neonicotinoids and fipronil}

Since their commercialization in 1991, neonicotinoids have been a useful tool for the control of various pests. The first case of resistance to neonicotinoids was reported in 1996, and later, a number of publications were devoted to this topic worldwide (Gorman et al. 2010). Increased use of insecticides exacerbates the development of resistance in most crop pests. In this regard, the use of neonicotinoids increased also rapidly after introduction of imidacloprid in several developed countries (Simon-Delso et al. 2015). The same situation has been observed since 2003 in the USA after the introduction of seedtreated crops in fields. The shift toward large-scale, prophylactic insecticide use was unprecedented, with $34-44 \%$ of soybeans and $79-100 \%$ of maize hectares treated in 2011 alone, contradicting previous expectations of using fewer insecticides than a decade or two ago (Douglas and Tooker 2015). One can expect, therefore, a rapid increase in pest resistance to all neonicotinoids in areas treated with coated seeds, as resistance mechanisms may develop rather quickly. For example, the cotton mealybug Phenacoccus solenopsis Tinsley (Hemiptera: Pseudococcidae) developed a 315 -fold greater resistance to acetamiprid after five rounds of selection in controlled conditions, although at the cost of reducing the biological fitness of the resistant populations (Afzal et al. 2015). Other authors found that the development of resistance to acetamiprid in cotton fields takes 7 years and is slower than resistance to other neonicotinoids, carbamates, organophosphorus, and pyrethroid insecticides (Ahmad and Akhtar 2016).

\section{Annual crops}

Potential for resistance to neonicotinoids in the pests of arable crops has been described (Clements et al. 2017), and some cases of outbreaks of pest populations have been described in annual crops (e.g., in Santos et al. 2016 for soybean treated with imidacloprid in Brazil). More specifically, Santos et al. (2016) studied the survival and fertility of the Neotropical brown stink bug Euschistus heros. Newly emerged adult females were exposed for $48 \mathrm{~h}$ imidacloprid residues equivalent to $1 \%$ of the field rate dose. Females exhibited reduced rates of survival but higher fecundity and fertility rates compared with untreated females. The authors showed that females of $E$. heros increased their reproductive output in response to the imidacloprid sublethal exposure. These findings suggest a potential involvement of sublethal exposure to neonicotinoids in the recent outbreaks of the Neotropical brown stink bug E. heros observed in Brazilian soybean-producing regions.

In rice crops, resistance of the brown planthopper (Nilaparvata lugens Stål) to imidacloprid was first detected in Thailand in 2003, and then in Vietnam, Japan, and other Asian countries (Matsumura et al. 2008). Resistance of this pest to neonicotinoids is widespread in China, with resistance ratios (RRs, the greater it is, the higher resistance) in 2012 ranging from 209- to 617 -fold. These values are much higher than in 2009. For thiamethoxam, the RR varied from 17 to 47 and for nitenpyram from 1.4 to 3.7 in 2012 (Zhang et al. 2014). Current levels of resistance are much higher than those reported 6 years earlier by Matsumura et al. in 2008. Similarly, populations of the whiteback planthopper Sogatella furcifera (Horvath) are resistant to fipronil in all countries of southeast Asia. In rice fields of Kumamoto, Japan, resistance of the small planthopper Laodelphax striatellus to fipronil has reached $R R>1,700$, whereas new compounds with the same MoA (e.g., fluralaner acting on GABA- and L-glutamategated chloride channels) can be more effective in controlling this pest (Asahi et al. 2015). It seems that the cytochrome P450 CYP6ER1 is significantly overexpressed in imidacloprid-resistant planthopper populations of southeast Asia (i.e., $N$. lugens and S. furcifera), with higher tolerance levels of 10 - to 90 -fold compared with a laboratorysusceptible strain. However, other pest populations showed different overexpression of variant $\mathrm{P} 450$ enzymes implicated in imidacloprid resistance (Garrood et al. 2016). One study found that a single mutation at a conserved position (Y151S) in two nAChR subunits, Nla1 and Nla3, is responsible for a substantial reduction in specific imidacloprid binding (Liu et al. 2005). Even the additional use of neonicotinoidspecific synergists such as IPPA08 does not seem to work so efficiently with resistant populations of planthoppers (Bao et al. 2016). Therefore, the best option to control that pest would be IPM strategies that do not use neonicotinoids. Interestingly, the IPM strategy has been adopted in the Philippines. Results showed that populations of the abovementioned planthopper in the Philippines remain susceptible to neonicotinoids (Matsumura et al. 2008) because of the 
many years implementing IPM with little use of insecticides in that country (Hadi et al. 2015). Actually, the obvious increase in resistance to systemic insecticides strongly suggests that management strategies other than chemical treatments are urgently needed to prevent damage by these pests.

In potato fields of North America, resistance of the Colorado potato beetle Leptinotarsa decemlineata (Say) to imidacloprid developed within 10 years after its introduction in 1995. By 2009, resistance affected more than $95 \%$ of the population of this pest in the Northeastern and Midwestern USA (Szendrei et al. 2012). High levels of resistance can be observed in areas within $100 \mathrm{~km}$ of the treated fields. It seems that the upregulation of three cytochrome P450s and a glutathione synthase-related protein provide a mechanistic explanation of resistance evolution in multiple resistant populations, but some of the resistant mechanisms involve also genetic changes and not just phenotypes (Clements et al. 2016). Resistance of this beetle species to another neonicotinoid, thiamethoxam, was first found in 2003 in a population from Massachusetts (Szendrei et al. 2012), further advocating that chemical control of this pest should be replaced with more rigorous application of IPM strategies.

In cotton crops, resistance of the tobacco thrips (Frankliniella fusca Hinds) to imidacloprid and thiamethoxam has developed faster than expected by earlier forecasts in southern areas of the USA. Some 57 and $65 \%$ of the populations monitored in 2015 showed resistance to the seed coated with neonicotinoids, with RR up to 55 and 39 for imidacloprid and thiamethoxam, respectively (Huseth et al. 2016). Resistance to thiamethoxam by the cotton aphid Aphis gossypii (Glover) has reached RRs between 29 and 526 in the USA (Gore et al. 2013), while in China, this pest shows a more moderate level of resistance to imidacloprid (RR of 42) and lesser values than for all other neonicotinoids (Shi et al. 2011).

The polyphagous and cosmopolitan whitefly Bemisia tabaci (Gennadius) is a devastating pest that can cause severe damage to a range of vegetable, fiber, and ornamental crops by direct feeding and by plant virus transmission. This species was the first to show resistance to imidacloprid and other neonicotinoids (Gorman et al. 2010). Cross-resistance among these compounds (Prabhaker et al. 2005) is threatening the chemical management program on genetically engineered cotton, where neonicotinoids are routinely being sprayed to manage sucking pests that have become dominant after the reduction in bollworms in the field (Basit et al. 2012).

The greenhouse whitefly Trialeurodes vaporariorum (Westwood) has also developed resistance to several neonicotinoids applied to vegetable crops in Europe and China (Table 4). The western flower thrip Frankliniella occidentalis (Pergande), which has invaded many horticultural and ornamental crops in China due to international trade, has developed up to 24-fold resistance to imidacloprid and up to 8.7-fold to acetamiprid (Wang et al. 2016a). This invasive pest also carries plant viruses that can decimate tomato and corn crops, so resistance to neonicotinoids strongly suggests that chemical control should be replaced with IPM strategies as well.

\section{Perennial crops}

Bass et al. (2015) reviewed most of the literature on pest resistance to neonicotinoids. Among pests of interest for perennial cropping systems, the green peach aphid Myzus persicae Sulzer has been involved in the highest number of reported cases of resistance among fruit trees. This appears to be a case of pre-selection resulting from host-plant adaptation (tolerance to nicotine by feeding on tobacco) and an expansion in host range. Resistance seems to be associated with metabolic detoxification by enhanced expression of cytochrome P450s. In some cases, it has also been found that modified penetration through the cuticle might contribute to resistance together with enhanced detoxification (Puinean et al. 2010). Target site resistance was also suggested as a mechanism inducing resistance in $M$. persicae (Bass et al. 2015). This was found to be associated to the R81T mutation in nAChR subunit genes in aphid populations from peach. Toda et al. (2017) developed a molecular diagnosis test for detecting the $\mathrm{R} 81 \mathrm{~T}$ mutation on the D-loop region of the $\beta 1$ subunit of the nAChR gene; this mutation confers resistance to neonicotinoids in the cotton aphid Aphis gossypii (Hemiptera: Aphididae). This mutation appears to be distributed in aphid populations on peach and closely related crops over southern Spain, southern France, and northern and central Italy and Greece (Bass et al. 2015; Voudouris et al. 2016). Bass et al. (2015) stressed the need to employ insecticides with different MoAs to reduce the selection pressure induced by neonicotinoids.

In orchards, $M$. persicae has become resistant to imidacloprid and thiacloprid in populations of southern Europe. In Italy, $65 \%$ of the aphids studied by Panini et al. (2014) had the neonicotinoid-specific R81T mutation while a few genotypes also revealed the involvement of P450-based metabolic resistance processes (Panini et al. 2014). The dominance level of insecticide resistance in this species suggests that the mutant allele $81 \mathrm{~T}$ is semi-recessive, with the wild $81 \mathrm{R}$ allele being rather dominant (Mottet et al. 2016). The neonicotinoid sulfoxaflor, a newly developed agonist of the nicotinic receptors (Giorio et al. 2017), appears to behave in a similar way in resistant strains of the same aphid M. persicae (Cutler et al. 2013), although some authors say is not affected by this mutation (Wang et al. 2016b). In populations of this aphid in Greece, over $58 \%$ of the clones collected in 2013 showed a 9- to 36-fold overexpression of the CYP6CY3 gene that codifies for the P450 detoxification mechanism (Voudouris et al. 2016). This is a matter of concern as tolerance can be developed very quickly by this mechanism. 


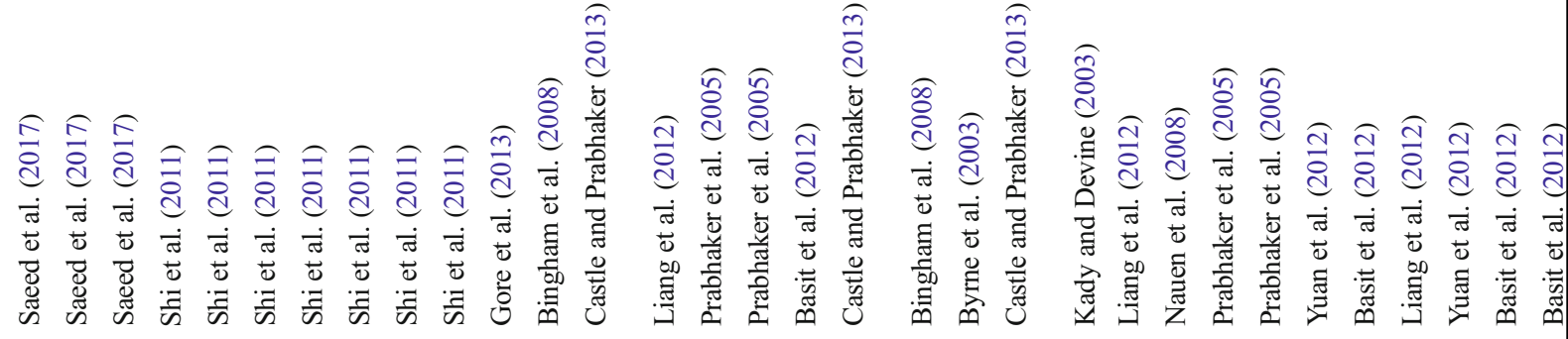

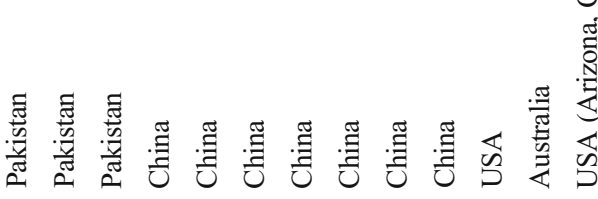<smiles></smiles>

高

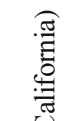

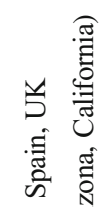

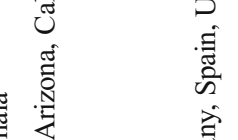

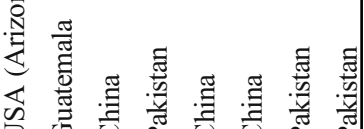

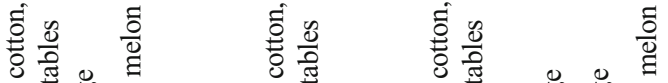

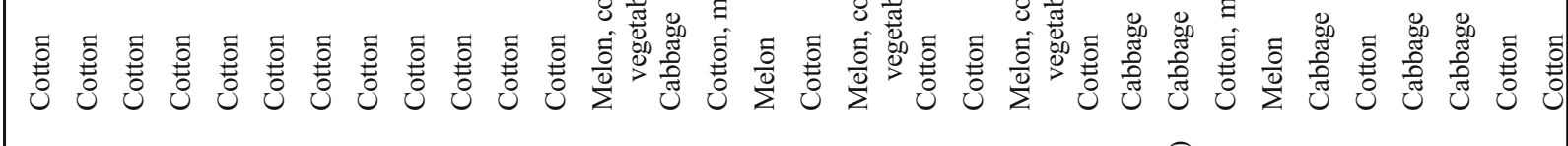

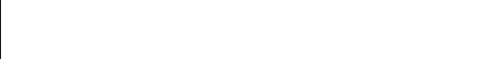

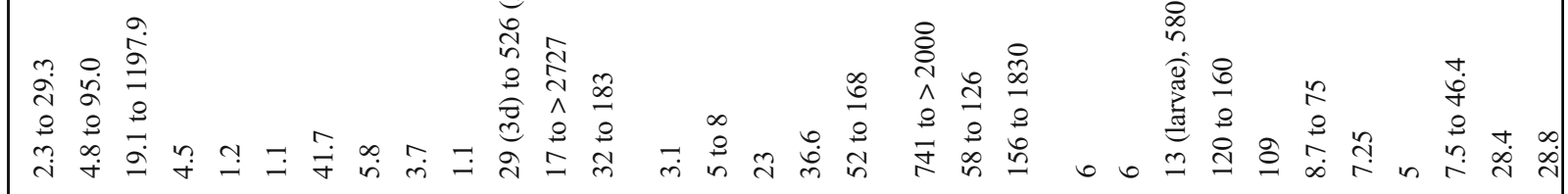

वิ 《

\section{曾}

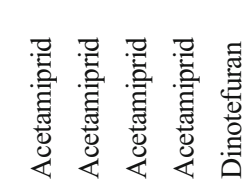

产

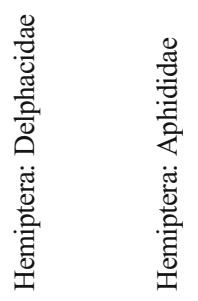

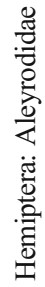

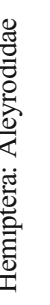




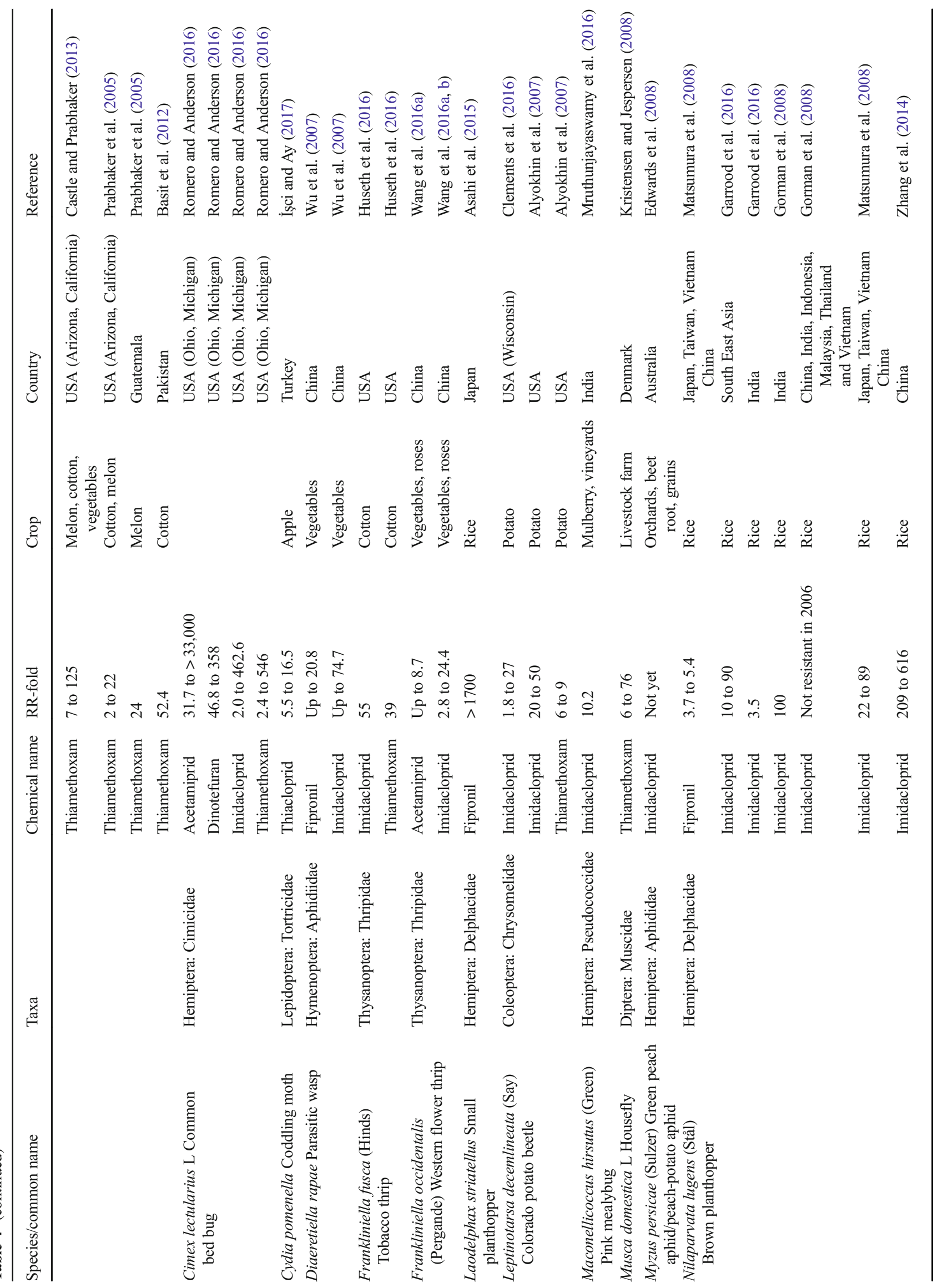




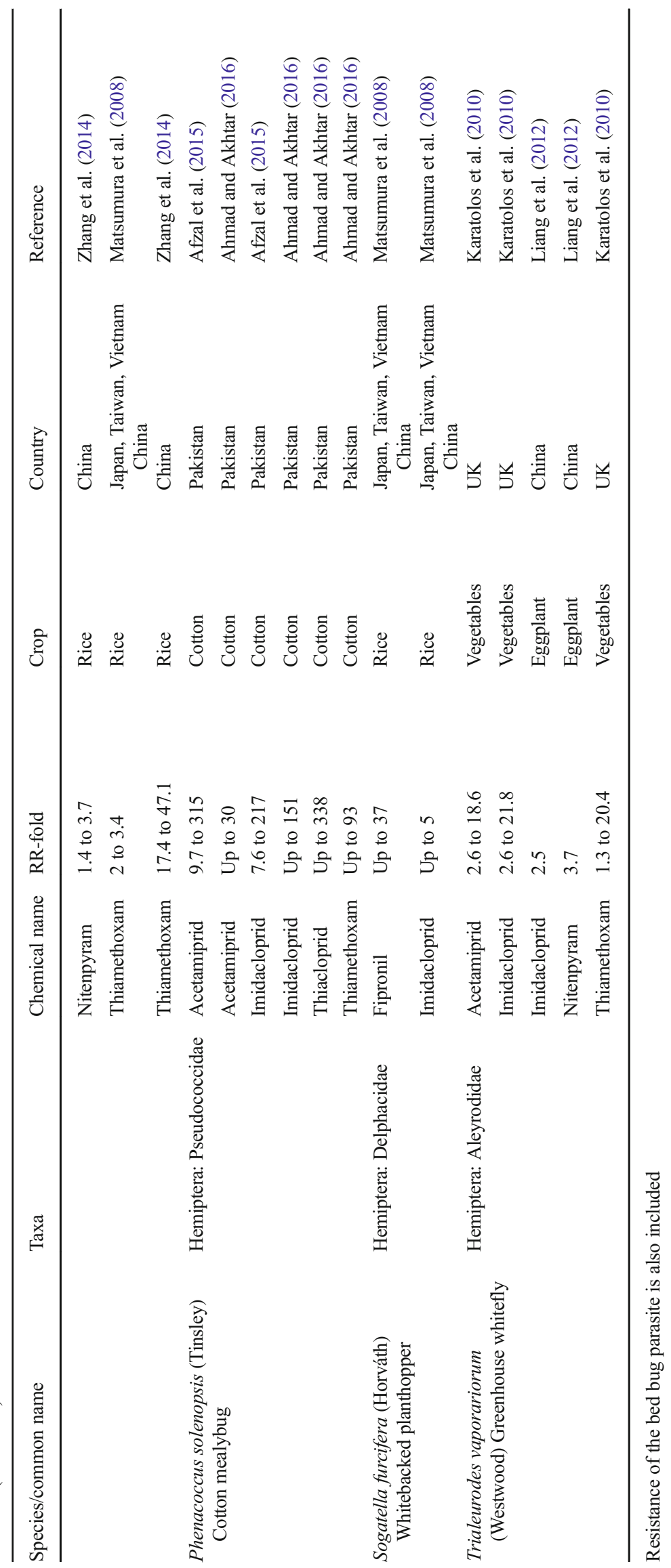


The most important pest of apple trees, the codling moth Cydia pomonella, has developed resistance to thiacloprid, with RRs between 5.5 and 16.5 measured in orchards of Turkey (İșci and Ay 2017). Resistance of this pest to thiacloprid is correlated with mixed-function oxidase activity (Reyes et al. 2007). This phenomenon seems to be spread across the world (Bass et al. 2015; İsci and Ay 2017) and is linked to cross-resistance to other compounds such as organophosphates: in this case, the resistance mechanism seems to be based on detoxification enzymes. In other studies on C. pomonella, a number of detoxification genes (CYP9A61, CpGST1, and CpCE-1) were differentially induced or suppressed by various insecticides (including imidacloprid) while expression of these genes was not influenced by acetamiprid when compared to the control (Yang et al. 2016).

Other authors have shown that over transcription of a single gene product, Cyp6g1, which is associated with the metabolic resistance to neonicotinoids in Drosophila melanogaster larvae, results in a significant increase of three imidacloprid metabolites in vivo (Joussen et al. 2008; Hoi et al. 2014). The high frequency of mutations and data obtained from these studies confirm the existence of multiple resistance mechanisms (e.g., enhanced detoxification, mutations, overexpression of enzymes), which may require different management strategies.

On the Asian citrus psyllid $D$. citri, a reduced sensitivity to neonicotinoids in certain populations of this pest in Florida has been found, raising concerns that resistance to neonicotinoids can hamper management of this pest (Tiwari et al. 2011). The promotion of effective rotations of insecticides and area-wide management of $D$. citri seems to have determined a reversal for insecticide resistance in this pest (Coy et al. 2016).

Western flower thrips, Frankliniella occidentalis (Pergande), is a generalist pest that can threaten fruit orchards and vineyards. Metabolic resistance to neonicotinoids has been reported for this pest, probably originating by crossresistance with other insecticides (Zhao et al. 1995; Minakuchi et al. 2013). In vineyards and mulberry groves of India, resistance of the pink mealybug (Maconellicoccus hirsutus Green) to imidacloprid have reached RR of 10.2-fold, similar to the tolerance found with other insecticidal classes (Mruthunjayaswamy et al. 2016).

Populations of the tea green leafhopper Empoasca vitis have been developing resistance to a number of insecticides in southeastern China, with high levels of cross resistance among imidacloprid, chlorfenapyr, and indoxacarb (Wei et al. 2017).

Resistance to neonicotinoids and fipronil has also been observed in beneficial insects. For instance, the parasitic wasp Diaeretiella rapae (Hymenoptera: Aphidiidae) showed crossresistance to fipronil and imidacloprid and is now 20 and 75 times respectively more resistant to these chemicals than in the past (Wu et al. 2004).
Indeed, among the most common pests of agricultural and ornamental crops, resistance to systemic insecticides is now widespread and develops quickly, as it typically involves enhanced detoxification by GST and P450 enzymatic systems. In the case of neonicotinoids, specific mutations of the $\alpha$ subunit of nAChRs confer long-term resistance to all chemicals of this class (Thany 2010). Highest resistance levels were found for imidacloprid, the first neonicotinoid launched to the market and lowest in the newest compounds like dinotefuran and nitenpyram (Shi et al. 2011; Zhang et al. 2014) - see Table 4. While resistance due to detoxification mechanisms can be overcome by using synergistic mixtures with other chemicals (Bingham et al. 2008; Basit et al. 2013; Darriet and Chandre 2013), the mutant-resistant individuals could be selected naturally rather quickly and eventually dominate the field populations of pests.

\section{Other resistance to neonicotinoids}

Pest resistance to neonicotinoids has been found not only in crops but also in the control of bed bugs (Cimex lectularius L.) in the USA. Consequently, formulations combining two neonicotinoids or a pyrethroid are currently becoming very popular in that country. However, high levels of resistance to four neonicotinoids, acetamiprid (up to RR of 33,000), imidacloprid ( $R R$ in the $2-463$ range), dinotefuran ( $R R$ in the 47-359 range), and thiamethoxam (RR in the 2.4-546 range) have already been detected in bed bug populations. In this case, detoxification mechanisms by induction of glutathione S-transferases (GST) and cytochrome P450s are responsible for the development of such resistance, thus limiting the options for chemical control of bed bugs (Romero and Anderson 2016).

\section{Concluding remarks}

Insecticides are expected to achieve higher yields and net incomes, but the relationship between yields and farmer's profits is not so obvious. For example, the effect of insecticides on yield may be negligible (see examples above), or quality products under organic/"integrated" cultivations may be sold at higher prices than conventional ones treated with insecticides, thus largely compensating reduced yields. An example at the scale of west and east Germany is given by Batáry et al. (2017). Another large-scale example is given here with mutual funds and IPM, which increased farmer profits while reducing the use of pesticides without negative impact on average yields and at the same time avoiding environmental impacts.

A review of the current literature on neonicotinoids and fipronil shows these systemic insecticides have a role in protecting certain crops against the damaging attacks of some 
soil pest such as wireworms and root worms and of sucking pests, in particular aphids, leafhoppers, thrips, mealybugs, and scale insects, as well as internal grubs that can only be reached by chemicals translocated within the plant. However, their efficacy does not guarantee an increase of yield of the crops they are protecting, particularly in pollinated crops. This is not unusual, as a recent study in France demonstrated that insecticide usage hardly accounts for any yield benefit in arable crops (Lechenet et al. 2017), mostly because plants compensate for the small damage that insects inflict them while the risk of a pest outbreak is small on a year-to-year basis.

Pest management can be implemented effectively by using the multi-faceted methods of IPM described succinctly in this paper. In addition, economic insurance initiatives, as described for the case of maize crops in Italy, can make up for farmers' losses in bad years, and they do not place any pressure on the environment, whereas neonicotinoids and fipronil do have large impacts on biodiversity, ecosystems, and ecosystem services worldwide (Pisa et al. 2017). In this sense, Europe is committed to continuing agricultural production while reducing significantly the amount of pesticide uses (Lescourret 2017) by making compulsory the use of IPM practices aimed at the preservation of environment and ecosystem services that sustain agricultural productivity (Sgolastra et al. 2017). Other countries (e.g., Canada) have taken regulatory decisions to reduce both non-agricultural and agricultural uses of neonicotinoids.

Here, we highlighted that the use of neonicotinoids is limited by the rapid development of resistance in target pests. Because many of the underlying mechanisms of resistance are common to other insecticide classes (e.g., pyrethroids, cholinesterase, inhibitors), the use of new neonicotinoids (e.g., sulfoxaflor, flupyradifurone; see Pisa et al. 2017) or substances with the same MoA is not the solution in the medium and longterm. It can even worsen impacts on non-target invertebrates by potential synergistic interactions with other neonicotinoids which are now everywhere in the environment (Mitchell et al. 2017). As Barzman et al. (2015) have said, "The future of crop production is now also threatened by emergence of pest resistance and declining availability of active substances. There is therefore a need to design cropping systems less dependent on synthetic pesticides." Moreover, it is the prophylactic uses of such systemic insecticides in seed treatments that should be urgently stopped since they are contrary to IPM practices. The tools for a new cropping system that does not rely on chemicals alone have been with us for years, but the implementation of the IPM practices is lacking (Hokkanen 2015) despite the initial aspirations of the EU directive establishing a framework for community action to achieve the sustainable use of pesticides (EU 2009).

In the meantime, the overwhelming evidence of negative effects on pollinators and arthropods needs to be weighed against the pest control benefits that these systemic insecticides are supposed to produce (Chagnon et al. 2015). Over-reliance on chemical control is associated with contamination of ecosystems (Bonmatin et al. 2015; Pisa et al. 2015; Mineau and Whiteside 2013; Beketov et al. 2013; Giorio et al. 2017) and undesirable health effects (Scott et al. 2014; Cimino et al. 2017; Wang et al. 2018), although in the case of neonicotinoids and fipronil, the scarcity of studies on human health to date preclude us from making a clear assessment. More effort is needed to investigate the effects induced by these agonists of the neuronal system after chronic human exposure (e.g., farmers and workers, exposure by drinks, food, treated pets and breeding animals, treated wood structures, air pollution, etc., and the sum of all these exposures) (Salis et al. 2017).

We hope that this review may help regulators to carefully consider the pros and cons of the continuous, increasing, and widespread use of these systemic insecticides. On a scientific basis, the efficiency of neonicotinoids and fipronil for pest control should be balanced against the drawbacks of their damage to natural enemies and other ecosystem services that sustain agricultural systems.

We have restricted this WIA to neonicotinoids and fipronil because they represent most of the insecticide market nowadays. However, regulators should consider that replacing one molecule by another in the future is not a sustainable strategy for agricultural production, as new molecules with the same MoA (e.g., sulfoxaflor, flupyradifurone) are additional threats to the environment and public health. Regulators should realize that a more restrictive regulatory framework is required for more sustainable agricultural practices such as IPM, with a strong willingness to use (present or future) highly toxic pesticides only as the last resort.

Acknowledgments The authors thank the Lune de Miel Foundation (France), the David Suzuki Foundation (Canada), the SumOfUs community (Germany), the Rovaltain Foundation (France), the Aurelia Foundation (Germany), and IUCN for their help in the dissemination of these updated WIA findings. The authors thank K.L. Heong, C. Pacteau, E. Lumawig-Heitzmann, J. Candilon Condiman, M. Petit, T. Brooks, and U. Drebber for the fruitful discussions and their help in this project. The TFSP members dedicate this work to the memory of Prof. Dr. Job van Praagh.

Funding information The Task Force on Systemic Pesticides (TFSP, www.tfsp.info) has been funded by the Triodos Foundation's Support Fund for Independent Research on Bee Decline and Systemic Pesticides. This Support Fund received donations from the Act Beyond Trust (Japan), Stichting Triodos Foundation (The Netherlands), M.A.O. C. Gravin van Bylandt Stichting (The Netherlands), Zukunft Stiftung Landwirtschaft (Germany), Hartmut Spaeter Umweltstiftung (Germany) , and citizens. The funders had no role in the study design, data collection and analysis, decision to publish, or preparation of the manuscript.

\section{Compliance with ethical standards}

Conflict of interest The authors declare that they have no competing interest. 
Open Access This article is distributed under the terms of the Creative Commons Attribution 4.0 International License (http:// creativecommons.org/licenses/by/4.0/), which permits unrestricted use, distribution, and reproduction in any medium, provided you give appropriate credit to the original author(s) and the source, provide a link to the Creative Commons license, and indicate if changes were made.

\section{References}

Afzal MBS, Shad SA, Abbas N, Ayyaz M, Walker WB (2015) Crossresistance, the stability of acetamiprid resistance and its effect on the biological parameters of cotton mealybug, Phenacoccus solenopsis (Homoptera: Pseudococcidae), in Pakistan. Pest Manag Sci. 71: $151-158$

Ahmad M, Akhtar S (2016) Development of resistance to insecticides in the invasive mealybug Phenacoccus solenopsis (Hemiptera: Pseudococcidae) in Pakistan. Crop Prot 88:96-102

Ahmad S, Pozzebon A, Duso C (2013) Augmentative releases of the predatory mite Kampimodromus aberrans in organic and conventional apple orchards. Crop Prot 52:47-56. https://doi.org/10.1016/j. cropro.2013.05.008

Alyokhin A, Dively G, Patterson M, Castaldo C, Rogers D, Mahoney M, Wollam J (2007) Resistance and cross-resistance to imidacloprid and thiamethoxam in the Colorado potato beetle Leptinotarsa decemlineata. Pest Manag Sci. 63:32-41

Andreev R, Kutinkova H, Rasheva D (2012) Non-chemical control of Aphis spiraecola Patch. and Dysaphis plantaginea Pass. on apple. J Biopesticides 5:239-242

Angeli G, Anfora G, Baldessari M, Germinara GS, Rama F, De Cristofaro A, Ioriatti C (2007) Mating disruption of codling moth Cydia pomonella with high densities of Ecodian sex pheromone dispensers. J Appl Entomol 131:311-318. https://doi.org/10.1111/j. 1439-0418.2007.01172.x

Asahi M, Kobayashi M, Matsui H, Nakahira K (2015) Differential mechanisms of action of the novel $\gamma$-aminobutyric acid receptor antagonist ectoparasiticides fluralaner (A1443) and fipronil. Pest Manag Sci. 71:91-95

Bao H, Shao X, Zhang Y, Deng Y, Xu X, Liu Z, Li Z (2016) Specific synergist for neonicotinoid insecticides: IPPA08, a cis-neonicotinoid compound with a unique oxabridged substructure. J Agric Food Chem. 64:5148-5155

Barzman M, Bàrberi P, Birch ANE, Boonekamp P, Dachbrodt-Saaydeh S, Graf B, Hommel B, Jensen JE, Kiss J, Kudsk P et al (2015) Eight principles of integrated pest management. Agron Sustain Develop. 35:1199-1215

Basit M, Sayyed AH, Saeed S, Saleem MA (2012) Lack of fitness costs associated with acetamiprid resistance in Bemisia tabaci (Hemiptera: Aleyrodidae). J Econ Entomol. 105:1401-1406

Basit M, Saeed S, Saleem MA, Sayyed AH (2013) Can resistance in Bemisia tabaci (Homoptera: Aleyrodidae) be overcome with mixtures of neonicotinoids and insect growth regulators? Crop Prot 44: $135-141$

Bass C, Denholm I, Williamson MS, Nauen R (2015) The global status of insect resistance to neonicotinoid insecticides. Pest Biochem Physiol 121:78-87

Batáry P, Gallé R, Riesch F, Fischer C, Dormann CF, Mußhoff O, Császár P, Fusaro S, Gayer C, Happe AK et al (2017) The former Iron Curtain still drives biodiversity-profit trade-offs in German agriculture. Nat Ecol Evol. https://doi.org/10.1038/s41559-017-0272-x

Beers EH, Schmidt RA (2014) Impacts of orchard pesticides on Galendromus occidentalis: Lethal and sublethal effects. Crop Prot 56:16-24. https://doi.org/10.1016/j.cropro.2013.10.010
Beers EH, Suckling DM, Prokopy RJ, Avilla J (2003) Apples: botany, production and uses. In: Ferree DC, Warrington IJ (eds) Ecology and management of apple arthropod pests. CABI Publishing, Wallingford, pp. 489-519. https://doi.org/10.1079/ 9780851995922.0489

Beers EH, Van Steenwyk RA, Shearer PW, Coates WW, Grant JA (2011) Developing Drosophila suzukii management programs for sweet cherry in the western United States. Pest Manag Sci. 67:1386-1395

Beketov MA, Kefford BJ, Schäfer RB, Liess M (2013) Pesticides reduce regional biodiversity of stream invertebrates. PNAS 110:11039-11043

Benefer CM, Knight ME, Ellis JS, Hicks H, Blackshaw RP (2012) Understanding the relationship between adult and larval Agriotes distributions: the effect of sampling method, species identification and abiotic variables. Appl Soil Ecol. 53:39-48. https://doi.org/10. 1016/j.apsoil.2011.11.004

Bijleveld van Lexmond M, Bonmatin JM, Goulson D, Noome DA (2015) Worldwide integrated assessment on systemic pesticides. Environ Sci Pollut Res. 22:1-4

Bingham G, Gunning RV, Delogu G, Borzatta V, Field LM, Moores GD (2008) Temporal synergism can enhance carbamate and neonicotinoid insecticidal activity against resistant crop pests. Pest Manag Sci. 64:81-85

Blackshaw RP, Hicks H (2013) Distribution of adult stages of soil insect pests across an agricultural landscape. J Pest Sci. 86:53-62. https:// doi.org/10.1007/s10340-012-0413-6

Bohnenblust E, Hull LA, Krawczyk G (2011) A comparison of various mating disruption technologies for control of two internally feeding Lepidoptera in apples. Entomol Exp Appl. 138:202-211. https://doi. org/10.1111/j.1570-7458.2010.01089.x

Bonmatin JM (2016) Néonicotinoïdes: impacts directs ou indirects sur les abeilles et la biodiversité \& développement des alternatives. Forum Eco-Tox de la Fondation Rovaltain, 11-13 October 2016. http:// fcsrovaltain.org/assets/4-8-s2-eco-tox2016 bonmatin.pdf. Assessed 21 Oct 2017

Bonmatin JM, Giorio C, Girolami V, Goulson D, Kreutzweiser DP, Krupke C, Liess M, Long E, Marzaro M, Mitchell EAD et al (2015) Environmental fate and exposure; neonicotinoids and fipronil. Environ Sci Pollut Res. 22:35-67

Bosch D, Rodríguez MA, Avilla J (2016) Captures of MFO-resistant Cydia pomonella adults as affected by lure, crop management system and flight. Bull Entomol Res. 106:54-62. https://doi.org/10. 1017/S0007485315000772

Brandl MA, Schumann M, Przyklenk M, Patel A, Vidal S (2017) Wireworm damage reduction in potatoes with an attract-and-kill strategy using Metarhizium brunneum. J Pest Sci. 90:479-493. https://doi.org/10.1007/s10340-016-0824-x

Broughton S, Rahman T (2017) Evaluation of lures and traps for male and female monitoring of Mediterranean fruit fly in pome and stone fruit. J Appl Entomol. 141:441-449

Brück E, Elbert A, Fischer R, Krueger S, Kühnhold J, Klueken AM, Nauen R, Niebes J, Reckmann U, Schnorbach H, Steffens R, van Waetermeulen X (2009) Movento ${ }^{\circledR}$, an innovative ambimobile insecticide for sucking insect pest control in agriculture: biological profile and field performance. Crop Prot 28:838-844. https://doi. org/10.1016/j.cropro.2009.06.015

Bruck DJ, Bolda M, Tanigoshi L, Klick J, Kleiber J, Defrancesco J, Gerdeman B, Spitler H (2011) Laboratory and field comparisons of insecticides to reduce infestation of Drosophila suzukii in berry crops. Pest Manag Sci. 67:1375-1385. https://doi.org/ $10.1002 /$ ps.2242

Budge GE, Garthwaite D, Crow A, Boatman ND, Delaplane KS, Brown MA, Thygesen HH, Pietra-Valle S (2015) Evidence for pollinator cost and farming benefits of neonicotinoid seed coatings on oilseed rape. Sci Rep. 5:12574. https://doi.org/10.1038/srep12574 
Buzzetti K, Chorbadjian RA, Nauen R (2015) Resistance management for San Jose Scale (Hemiptera: Diaspididae). J Econ Entomol. 108: 2743-2752

Byrne FJ, Castle S, Prabhaker N, Toscano NC (2003) Biochemical study of resistance to imidacloprid in B biotype Bemisia tabaci from Guatemala. Pest Manag Sci. 59:347-352

Calkins CO, Faust RJ (2003) Overview of areawide programs and the program for suppression of codling moth in the western USA directed by the United States Department of Agriculture-Agricultural Research Service. Pest Manag Sci. 59:601-604. https://doi.org/10. $1002 /$ ps.712

Castle SJ, Prabhaker N (2013) Monitoring changes in Bemisia tabaci (Hemiptera: Aleyrodidae) susceptibility to neonicotinoid insecticides in Arizona and California. J Econ Entomol. 106:1404-1413

Castro A, Lacerda M, Zanuncio T, Ramalho FS, Polanczyk R, Serrão J, Zanuncio J (2012) Effect of the insect growth regulator diflubenzuron on the predator Podisus nigrispinus (Heteroptera: Pentatomidae). Ecotoxicology 21:96-103

Chagnon M, Kreutzweiser D, Mitchell ED, Morrissey CA, Noome DA, Van der Sluijs JP (2015) Risks of large-scale use of systemic insecticides to ecosystem functioning and services. Environ Sci Pollut Res. 22:119-134

Cichon LI, Garrido SAS, Lago JD, Menni MF (2013) Control of green peach aphid Myzus persicae in organic plum orchards (conference paper). Acta Hortic. 1001:115-120. https://doi.org/10.17660/ ActaHortic.2013.1001.11

Cimino AM, Boyles AL, Thayer KA, Perry MJ (2017) Effects of neonicotinoid pesticide exposure on human health: a systematic review. Environ Health Perspect. 125:155-162

Clements J, Schoville S, Peterson N, Lan Q, Groves RL (2016) Characterizing molecular mechanisms of imidacloprid resistance in select populations of Leptinotarsa decemlineata in the Central Sands Region of Wisconsin. PLoS One 11:e0147844

Clements J, Schoville S, Clements N, Chapman RGL (2017) Temporal patterns of imidacloprid resistance throughout a growing season in Leptinotarsa decemlineata populations. Pest Manag Sci. 3:641-650

Cocco A, Lentini A, Serra G (2014) Mating disruption of Planococcus ficus (Hemiptera: Pseudococcidae) in vineyards using reservoir pheromone dispensers. J Insect Sci 14(1):144. https://doi.org/10. 1093/jisesa/ieu006

Cocco A, Marras PM, Muscas E, Mura A, Lentini A (2015) Variation of life-history parameters of Planococcus ficus (Hemiptera: Pseudococcidae) in response to grapevine nitrogen fertilization. J Appl Entomol. 139:519-528. https://doi.org/10.1111/jen.12192

Costello MJ (2008) Regulated deficit irrigation and density of Erythroneura spp. (Hemiptera: Cicadellidae) on grape. J Econ Entomol. 101:1287-1294. https://doi.org/10.1603/00220493(2008)101[1287:RDIADO]2.0.CO;2

Costello MJ, Daane KM (2003) Spider and leafhopper (Erythroneura spp.) response to vineyard ground cover. Environ Entomol. 32: 1085-1098. https://doi.org/10.1603/0046-225X-32.5.1085

Coy MR, Bin L, Stelinski LL (2016) Reversal of insecticide resistance in Florida populations of Diaphorina citri (Hemiptera: Liviidae). Fla Entomol 99:26-32

Cross JV, Solomon MG, Chandler D, Jarrett P, Richardson PN, Winstanley D, Bathon H, Huber J, Keller B, Langenbruch GA, Zimmermann G (1999) Biocontrol of pests of apples and pears in northern and central Europe: 1. Microbial agents and nematodes. Biocontrol Sci Technol. 9:125-149. https://doi.org/10.1080/ 09583159929721

Cutler P, Slater R, Edmunds AJF, Maienfisch P, Hall RG et al (2013) Investigating the mode of action of sulfoxaflor: a fourth-generation neonicotinoid. Pest Manag Sci. 69:607-619

Daane KM, Williams LE (2003) Manipulating vineyard irrigation amounts to reduce insect pest damage. Ecol Appl. 13:1650-1666. https://doi.org/10.1890/02-5328
Daane KM, Yokota GY, Zheng Y, Hagen KS (1996) Inundative release of common green lacewings (Neuroptera: Chrysopidae) to suppress Erythroneura variabilis and E. elegantula (Homoptera: Cicadellidae) in vineyards. Environ Entomol. 25:1224-1234. https://doi.org/10.1093/ee/25.5.1224

Daane KM, Malakar-Kuenen RD, Walton VM (2004) Temperaturedependent development of Anagyrus pseudococci (Hymenoptera: Encyrtidae) as a parasitoid of the vine mealybug, Planococcus ficus (Homoptera: Pseudococcidae). Biol Control 31:123-132

Daane KM, Bentley WJ, Millar JG, Walton VM, Cooper ML, Biscay P, Yokota GY (2008) Integrated management of mealybugs in California vineyards. Acta Hortic. 785:235-252. https://doi.org/10. 17660/ActaHortic.2008.785.30

Darriet F, Chandre F (2013) Efficacy of six neonicotinoid insecticides alone and in combination with deltamethrin and piperonyl butoxide against pyrethroid-resistant Aedes aegypti and Anopheles gambiae (Diptera: Culicidae). Pest Manag Sci. 69:905-910

Deguines N, Jono C, Baude M, Henry M, Julliard R, Fontaine C (2014) Large-scale trade-off between agricultural intensification and crop pollination services. Front Ecol Environ. 12:212-217

Dercks W, Hackel S, Witte H, Michaelsen M, Neuber M, Gärber U, Kleeberg H (2014) Plant Protection with Plant Extracts (Botanicals): background, Two Case Studies, Conclusions and Positioning | [PflanzenschutzmitPflanzenextrakten (Botanicals): Hintergründe, zweiFallstudien, Schlussfolgerungen und Standortbestimmung] Gesunde Pflanzen 66: 1-16. https://link. springer.com/article/10.1007\%2Fs10343-013-0313-6. Assessed 12 July 2017

Dib H, Sauphanor B, Capowiez Y (2010) Effect of codling moth exclusion nets on the rosy apple aphid, Dysaphis plantaginea, and its control by natural enemies. Crop Prot 29:1502-1513. https://doi. org/10.1016/j.cropro.2010.08.012

Dib H, Sauphanor B, Capowiez Y (2016) Effect of management strategies on arthropod communities in the colonies of rosy apple aphid, Dysaphis plantaginea Passerini (Hemiptera: Aphididae) in southeastern France. Agric Ecosyst Environ. 216:203-206. https://doi. org/10.1016/j.agee.2015.10.003

Dobson RC, Rogers M, Moore JL, Bessin RT (2016) Exclusion of the brown marmorated stink bug from organically grown peppers using barrier screens. Hortic Technol. 26:191-198

Douglas M, Tooker JF (2015) Large-scale deployment of seed treatments has driven rapid increase in use of neonicotinoid insecticides and preemptive pest management in U.S. field crops. Environ Sci Technol. 49:5088-5097

Douglas M, Tooker JF (2016) Meta-analysis reveals that seed-applied neonicotinoids and pyrethroids have similar negative effects on abundance of arthropod natural enemies. PeerJ 4:e2776. https:// doi.org/10.7717/peerj.2776

Duso C, Vettorazzo E (1999) Mite population dynamics on different grape varieties with or without phytoseiids released (Acari: Phytoseiidae). Exp Appl Acarol 23:741-763. https://doi.org/10. 1023/A:1006297225577

Duso C, Trentin R, Borgo M, Egger E (1985) Influenza della termoregolazione estiva mediante acqua sulle popolazioni di Planococcus ficus Sign. su vite. Rivista di Viticoltura e di Enologia 38:567-607

Duso C, Fontana P, Malagnini V (2004) Diversity and abundance of phytoseiid mites (acari: phytoseiidae) in vineyards and the surrounding vegetation in northeastern Italy. Acarologia 44:31-47 https:// www1.montpellier.inra.fr/cbgp/acarologia/export_pdf.php?id= 42\&typefile=pd. Assessed 09 September 2017

Duso C, Pozzebon A, Kreiter S, Tixier M, Candolfi M (2012) Management of phytophagous mites in European Vineyards. In: Bostanian NJ, Vincent C, Isaacs R (eds) Arthropod management in vineyards: pests, approaches, and future directions. Springer, Netherlands, pp 191-217 
Duso C, Ahmad S, Tirello P, (...), Malagnini V, Angeli G (2014) The impact of insecticides applied in apple orchards on the predatory mite Kampimodromus aberrans (Acari: Phytoseiidae). Exp Appl Acarol 62:391-414

Edwards OR, Franzmann B, Thackray D, Micic S (2008) Insecticide resistance and implications for future aphid management in Australian grains and pastures: a review. Aust J Exp Agric. 48: $1523-1530$

El Wakeil NE, Farghaly HT, Ragab ZA (2008) Efficacy of inundative releases of Trichogramma evanescens in controlling Lobesia botrana in vineyards in Egypt. J Pest Sci. 81:49-55. https://doi. org/10.1007/s10340-007-0184-7

EU (2009) Directive 2009/128/EC of the European Parliament and of the Council of 21 October 2009 establishing a framework for Community action to achieve the sustainable use of pesticides, OJ EU L309, 71-86, 24.11.2009

EU (2013a) Commission implementing Regulation (EU) No 485/2013 of 24 May 2013 amending Implementing Regulation (EU) No 540/ 2011, as regards the conditions of approval of the active substances clothianidin, thiamethoxam and imidacloprid, and prohibiting the use and sale of seeds treated with plant protection products containing those active substances. OJ EU L139, 12-26, 25.05.2013

EU (2013b) Commission implementing Regulation (EU) No 781/2013 of 14 August 2013 amending Implementing Regulation (EU) No 540/ 2011, as regards the conditions of approval of the active substance fipronil, and prohibiting the use and sale of seeds treated with plant protection products containing this active substances. OJ EU L219, $22-25,15.08 .2013$

Ferrari R, Tassini C, Furlan L, Fracasso F, Sartori E, Codato F, Bin O (2015) La gestione degli elateridi con i fondi mutualistici. Terra e Vita 14:42-45 (in Italian). http://novagricoltura.edagricole.it/wpcontent/uploads/sites/10/2015/04/La-gestione-degli-elateridiPagine-da-TV14-2015-2.pdf, assessed 9 September 2017

Fornasiero D, Duso C, Pozzebon A, Tomasi D, Gaiotti F, Pavan F (2012) Effects of irrigation on the seasonal abundance of Empoasca vitis in North-Italian vineyards. J Econ Entomol. 105:176-185. https://doi. org/10.1603/EC11218

Fornasiero D, Pavan F, Pozzebon A, Picotti P, Duso C (2016) Relative infestation level and sensitivity of grapevine cultivars to the leafhopper Empoasca vitis (Hemiptera: Cicadellidae). J Econ Entomol. 109(1):416-25. https://doi.org/10.1093/jee/tov313

Furlan L (2014) IPM thresholds for Agriotes wireworm species in maize in southern Europe. J Pest Sci. 87:609-617. https://doi.org/10.1007/ s10340-014-0583-5

Furlan L, Kreutzweiser D (2015) Alternatives to neonicotinoid insecticides for pest control: case studies in agriculture and forestry. Environ Sci Pollut Res. 22:135-147. https://doi.org/10.1007/ s11356-014-3628-7

Furlan L, Contiero B, Sartori E, Fracasso F, Sartori A, Vasileiadis VP, Sattin M (2015) Mutual funds are a key tool for IPM implementation: a case study of soil insecticides in maize shows the way. IPM Innovation in Europe, Poznan 14-16 January, Abstract book, 159. http://www.pure-ipm.eu/sites/default/files/content/files/Book\% 20 of $\% 20$ Abstracts $\% 20-\% 20$ IPM\%20Innovation $\% 20$ in $\%$ 20Europe sessions-annuals.pdf. Assessed 9 Sept 2017

Furlan L, Vasileiadis VP, Chiarini F, Huiting H, Leskovšek R, Razinger J, Holbe JI, Sartori E, Urek G, Verschweleg A, Benevegnù I, Sattin M (2016) Risk assessment of soil-pest damage to grain maize in Europe within the framework of integrated pest management. Crop Prot 97:52-59. https://doi.org/10.1016/j.cropro.2016.11.029

Furlan L, Contiero B, Chiarini F, Colauzzi M, Sartori E, Benevegnù I, Giandon P (2017) Risk assessment of maize damage by wireworms (Coleoptera: Elateridae) as the first step in implementing IPM and in reducing the environmental impact of soil insecticides. Environ Sci Pollut Res. 24:236-251. https://doi.org/10.1007/s11356-016-7692-Z
Gallardo A, López MÁ, Lara M, Maistrello L, Molejón A, Ocete R (2016) Resurgence of minor pests following the implementation of mating disruption against Lobesia botrana (Denis \& Schiffermüller) (Lepidoptera, Tortricidae) in Sherry vineyards (Spain). Vitis J Grapevine Res 55:37-43. https://doi.org/10. 5073/vitis.2016.55.37-43

Garrood WT, Zimmer CT, Gorman KJ, Nauen R, Bass C, Davies TGE (2016) Field-evolved resistance to imidacloprid and ethiprole in populations of brown planthopper Nilaparvata lugens collected from across south and east Asia. Pest Manag Sci. 72:140-149

Gibbons D, Morrissey C, Mineau P (2015) A review of the direct and indirect effects of neonicotinoids and fipronil on vertebrate wildlife. Environ Sci Pollut Res. 22:103-118

Giorio C, Anton Safer A, Sánchez-Bayo F, Tapparo A, Lentola A, Girolami V, Bijleveld van Lexmond M, Bonmatin JM (2017) An update of the Worldwide Integrated Assessment (WIA) on systemic insecticides. Part 1: new molecules, metabolism, fate and transport. Environ Sci Pollut Res. https://doi.org/10.1007/s11356-017-0394-3

Gore J, Cook D, Catchot A, Leonard BR, Stewart SD, Lorenz G, Kerns D (2013) Cotton aphid (Heteroptera: Aphididae) susceptibility to commercial and experimental insecticides in the southern United States. J Econ Entomol. 106:1430-1439

Gorman K, Liu Z, Denholm I, Brüggen K-U, Nauen R (2008) Neonicotinoid resistance in rice brown planthopper, Nilaparvata lugens. Pest Manag Sci. 64:1122-1125

Gorman K, Slater R, Blande JD, Clarke A, Wren J, McCaffery A, Denholm I (2010) Cross-resistance relationships between neonicotinoids and pymetrozine in Bemisia tabaci (Hemiptera: Aleyrodidae). Pest Manag Sci. 66:1186-1190

Gurr GM, Heong KL, Cheng JA, Catindig J (2012) Ecological engineering against insect pests in Asian irrigated rice. In: Gurr GM, Wratten SD, Snyder WE, Read DMY (eds) Biodiversity and insect pests: key issues for sustainable management. John Wiley \& Sons, Ltd., UK, pp 214-229

Gurr GM, Lu Z, Zheng X, Xu H, Zhu P, Chen G, Yao X, Cheng J, Zhu Z, Catindig JL et al (2016) Multi-country evidence that crop diversification promotes ecological intensification of agriculture. Nature Plants 2:16014. https://doi.org/10.1038/nplants.2016.14

Hadi BAR, García CPF, Heong KL (2015) Susceptibility of Nilaparvata lugens (Hemipteran: Delphacidae) populations in the Philippines to insecticides. Crop Prot 76:100-102

Heong KL, Escalada MM, Chien HV, Cuong LQ (2014) Restoration of rice landscape biodiversity by farmers in Vietnam through education and motivation using media. Surv Perspect Integrating Environ Soc (S.A.P.I.EN.S.) 7(2). http://sapiens.revues.org/1578. Assessed 9 Aug 2017

Herbert KS, Hoffmann AA, Powell KS (2008) Assaying the potential benefits of thiamethoxam and imidacloprid for phylloxera suppression and improvements to grapevine vigour. Crop Prot 27:1229-1236

Hermann A, Brunner N, Hann P, Wrbka T, Kromp B (2013) Correlations between wireworm damages in potato fields and landscape structure at different scales. J Pest Sci. 86:41-51. https://doi.org/10.1007/ s10340-012-0444-Z

Hoi KK, Daborn PJ, Battlay P, Robin C, Batterham P, O'Hair RAJ, Donald WA (2014) Dissecting the insect metabolic machinery using twin ion mass spectrometry: a single P450 enzyme metabolizing the insecticide imidacloprid in vivo. Anal Chem. 86:3525-3532

Hokkanen HMT (2015) Integrated pest management at the crossroads: science, politics, or business (as usual)? Arthropod-Plant Interactions 9:543-545

Hokkanen HMT, Menzler-Hokkanen I, Keva M (2017) Long-term yield trends of insect-pollinated crops vary regionally and are linked to neonicotinoid use, landscape complexity, and availability of pollinators. Arthropod-Plant Interactions 11:449-461 
Huseth AS, Chappell TM, Langdon K, Morsello SC, Martin S et al (2016) Frankliniella fusca resistance to neonicotinoid insecticides: an emerging challenge for cotton pest management in the eastern United States. Pest Manag Sci. 72:1934-1945

Ichinose K, Bang DV, Tuan DH, Dien LQ (2010) Effective use of neonicotinoids for protection of citrus seedlings from invasion by Diaphorina citri (Hemiptera: Psyllidae). J Econ Entomol. 103:127-135

Ioriatti C, Lucchi A (2016) Semiochemical strategies for tortricid moth control in apple orchards and vineyards in Italy. J Chem Ecol. 42: $571-583$

Ioriatti C, Anfora G, Tasin M, De Cristofaro A, Witzgall P, Lucchi A (2011) Chemical ecology and management of Lobesia botrana (Lepidoptera: Tortricidae). J Econ Entomol. 104:1125-1137. https://doi.org/10.1603/EC10443

İșci M, Ay R (2017) Determination of resistance and resistance mechanisms to thiacloprid in Cydia pomonella L. (Lepidoptera: Tortricidae) populations collected from apple orchards in Isparta Province, Turkey. Crop Prot 91:82-88

Jepsen SJ, Rosenheim JA, Bench ME (2007) The effect of sulfur on biological control of the grape leafhopper, Erythroneura elegantula, by the egg parasitoid Anagrus erythroneurae. BioControl 52:721732. https://doi.org/10.1007/s10526-006-9058-9

Jones MM, Robertson JL, Weinzierl RA (2010) Susceptibility of oriental fruit moth (Lepidoptera: Tortricidae) larvae to selected reduced-risk insecticides. J Econ Entomol. 103:1815-1820

Joussen N, Heckel DG, Haas M, Schuphan I, Schmidt B (2008) Metabolism of imidacloprid and DDT by P450 CYP6G1 expressed in cell cultures of Nicotiana tabacum suggests detoxification of these insecticides in Cyp6g1-overexpressing strains of Drosophila melanogaster, leading to resistance. Pest Manag Sci. 64:65-73

Jung J, Racca P, Schmitt J, Kleinhenz B (2014) SIMAGRIO-W: development of a prediction model for wireworms in relation to soil moisture, temperature and type. J Appl Entomol. 138:183-194. https://doi.org/10.1111/jen.12021

Kabaluk T (2014) Targeting adult Elateridae as a concept for wireworm biocontrol. BioControl 59:607. https://doi.org/10.1007/s10526-0149603-X

Kabaluk JT, Ericsson JD (2007) Metarhizium anisopliae seed treatment increases yield of field corn when applied for wireworm control. Agron J. 99:1377-1391

Kabaluk JT, Vernon RS, Goettel MS (2007) Mortality and infection of Agriotes obscurus (Coleoptera: Elateridae) with inundative field applications of Metarhizium anisopliae. Phytoprotection 88:51-56

Kabaluk JT, LaFontaine JP, Borden JH (2015) An attract and kill tactic for click beetles based on Metarhiziumbrunneumand a new formulation of sex pheromone. J Pest Sci. 88:707-716

Kady HE, Devine GJ (2003) Insecticide resistance in Egyptian populations of the cotton whitefly, Bemisia tabaci (Hemiptera: Aleyrodidae). Pest Manag Sci. 59:865-871

Karatolos N, Denholm I, Williamson M, Nauen R, Gorman K (2010) Incidence and characterisation of resistance to neonicotinoid insecticides and pymetrozine in the greenhouse whitefly, Trialeurodes vaporariorum Westwood (Hemiptera: Aleyrodidae). Pest Manag Sci. 66:1304-1307

Kovács-Hostyánszki A, Espíndola A, Vanbergen AJ, Settele J, Kremen C, Dicks LV (2017) Ecological intensification to mitigate impacts of conventional intensive land use on pollinators and pollination. Ecol Lett. 20:673-689

Kristensen M, Jespersen JB (2008) Susceptibility to thiamethoxam of Musca domestica from Danish livestock farms. Pest Manag Sci. 64:126-132

Kuhar TP, Kamminga K (2017) Review of the chemical control research on Halyomorpha halys in the USA. J Pest Sci. 90:1021-1031

Kuhar TP, Short BD, Krawczyk G, Leskey TC (2017) Deltamethrinincorporated nets as an integrated pest management tool for the invasive Halyomorpha halys (Hemiptera: Pentatomidae). J Econ Entomol. 110:543-545

Lacey LA, Shapiro-Ilan DI (2008) Microbial control of insect pests in temperate orchard systems: potential for incorporation into IPM. Annu Rev Entomol. 53:121-144. https://doi.org/10.1146/annurev. ento.53.103106.093419

Lacey LA, Arthurs SP, Unruh TR, Headrick H, Fritts R Jr (2006) Entomopathogenic nematodes for control of codling moth (Lepidoptera: Tortricidae) in apple and pear orchards: effect of nematode species and seasonal temperatures, adjuvants, application equipment, and post-application irrigation. Biol Control 37:214 223. https://doi.org/10.1016/j.biocontrol.2005.09.015

Leach H, Van Timmeren S, Isaacs R (2016) Exclusion netting delays and reduces Drosophila suzukii (Diptera: Drosophilidae) infestation in raspberries. J Econ Entomol. 109:2151-2158

Lechenet M, Dessaint F, Py G, Makowski D, Munier-Jolain N (2017) Reducing pesticide use while preserving crop productivity and profitability on arable farms. Nat Plants 3:17008

Lee WW, Shin TY, Bae SM, Woo SD (2015) Screening and evaluation of entomopathogenic fungi against the green peach aphid, Myzus persicae using multiple tools. J Asia-Pac Entomol. 18:607-615

Lefort F, Fleury D, Fleury I, Coutant C, Kuske S, Kehrli P, Maignet P (2014) Pathogenicity of entomopathogenic fungi to the green peach aphid Mmyzus persicae Ssulzer (Aphididae) and the european tarnished bug Llygus rugulipennis poppius (Miridae). Egyptian J Biol Pest Control 24:379-386

Lescourret F (2017) Toward a reduced use of pesticides in European farming systems: an introduction to the PURE project. Crop Prot 97:7-9

Leskey TC, Lee D, Short BD, Wright SE (2012) Impact of insecticides on the invasive Halyomorpha halys (Hemiptera: Pentatomidae): analysis of insecticide lethality. J Econ Entomol. 105:1726-1735. https:// doi.org/10.1603/EC12265

Liang P, Tian Y-A, Biondi A, Desneux N, Gao X-W (2012) Short-term and transgenerational effects of the neonicotinoid nitenpyram on susceptibility to insecticides in two whitefly species. Ecotoxicology 21:1889-1898

Liu Z, Williamson MS, Lansdell SJ, Denholm I, Han Z, Millar NS, Casida JE (2005) A nicotinic acetylcholine receptor mutation conferring target-site resistance to imidacloprid in Nilaparvata lugens (Brown Planthopper). PNAS 102:8420-8425

Lowery DT, Smirle MJ, Foottit RG, Zurowski CL, Beers Peryea EH (2005) Baseline susceptibilities to imidacloprid for green apple aphid and spirea aphid (Homoptera: Aphididae) collected from apple in the Pacific Northwest. J Econ Entomol. 98:188-194. https:// doi.org/10.1603/0022-0493-98.1.188

Lu Z, Zhu P, Gurr GM, Zheng X, Chen G, Heong KL (2015) Rice Pest Management by Ecological Engineering: A Pioneering Attempt in China. In: Heong K, Cheng J, Escalada M (eds) Rice Planthoppers. Springer, Dordrecht, pp 161-178. https://doi.org/10.1007/978-94017-9535-7_8. Assessed 9 Aug 2017

Maalouly M, Franck P, Bouvier J, Toubon J, Lavigne C (2013) Codling moth parasitism is affected by semi-natural habitats and agricultural practices at orchard and landscape levels. Agric Ecosyst Environ. 169:33-42. https://doi.org/10.1016/j.agee.2013.02.008

Macfadyen S, Hardie DC, Fagan L, Stefanova K, Perry KD, DeGraaf HE, Holloway J, Spafford H, Umina PA (2014) Reducing insecticide use in broad-acre grains production: an Australian study. PLoS One 9: e89119

Magalhaes LC, Walgenbach JF (2011) Life stage toxicity and residual activity of insecticides to codling moth and oriental fruit moth (Lepidoptera: Tortricidae). J Econ Entomol. 104:1950-1959

Malagnoux L, Capowiez Y, Rault M (2015) Impact of insecticide exposure on the predation activity of the European earwig Forficula auricularia. Environ Sci Pollut Res. 22:14116-14126. https://doi. org/10.1007/s11356-015-4520-9 
Marchand PA (2015) Basic Substances: an approval opportunity for low concern natural products under EU pesticide regulation. Pest Manag Sci. 71:1197-1200. https://doi.org/10.1002/ps.3997

Marchand PA (2016) Basic substances under EC 1107/2009 phytochemical regulation: experience with non-biocide and food products as biorationals. J Plant Protect Res. 56:312-318. https://doi.org/10. 1515/jppr-2016-0041h

Marchand PA (2017) Basic substances under EU pesticide regulation: an opportunity for organic production? Org Farming 3:16-19. https:// doi.org/10.12924/of2017.03010016

Markó V, Blommers LHM, Bogya S, Helsen H (2008) Kaolin particle films suppress many apple pests, disrupt natural enemies and promote woolly apple aphid. J Appl Entomol. 132:26-35. https://doi. org/10.1111/j.1439-0418.2007.01233.x

Matsumura M, Takeuchi H, Satoh M, Sanada-Morimura S, Otuka A, Watanabe T, van Thanh D (2008) Species-specific insecticide resistance to imidacloprid and fipronil in the rice planthoppers Nilaparvata lugens and Sogatella furcifera in east and south-east Asia. Pest Manag Sci. 64:1115-1121

Matyjaszczyk E, Sobczak J, Szulc M (2015) Is the possibility of replacing seed dressings containing neonicotinoids with other means of protection viable in major Polish agricultural crops? J Plant Protect Res. 55:329-335

Mertz FP, Yao RC (1990) Saccharopolyspora spinosa sp. nov. isolated from soil collected in a sugar mill rum still. Int J Syst Bacteriol. 40: 34-39. https://doi.org/10.1099/00207713-40-1-34

Milosavljević I, Esser AD, Crowder DW (2016) Seasonal population dynamics of wireworms in wheat crops in the Pacific Northwestern United States. J Pest Sci. 90:77-86. https://doi.org/ 10.1007/s10340-016-0750-y

Minakuchi C, Inano Y, Shi XY, Song DL, Zhang YJ, Miura K (2013) Neonicotinoid resistance and cDNA sequences of nicotinic acetylcholine receptor subunits of the western flower thrips Frankliniella occidentalis (Thysanoptera: Thripidae). Appl Entomol Zool. 48: 507-513

Mineau P, Whiteside M (2013) Pesticide acute toxicity is a better correlate of U.S. grassland bird declines than agricultural intensification. PLoS One 8:e57457

Mitchell EAD, Mulhauser B, Mulot M, Mutabazi A, Glauser G, Aebi A (2017) A worldwide survey of neonicotinoids in honey. Science 358:109-111. https://doi.org/10.1126/science.aan3684

Monteiro LB, Lavigne C, Ricci B, Franck P, Toubon J-F, Sauphanor B (2013) Predation of codling moth eggs is affected by pest management practices at orchard and landscape levels. Agric Ecosyst Environ. 166:86-93. https://doi.org/10.1016/j.agee.2011.10.012

Mota-Sánchez D, Wise JC, Poppen RV, Gut LJ, Hollingworth RM (2008) Resistance of codling moth, Cydia pomonella (L.) (Lepidoptera: Tortricidae), larvae in Michigan to insecticides with different modes of action and the impact on field residual activity. Pest Manag Sci. 64:881-890. https://doi.org/10.1002/ps.1576

Mottet C, Fontaine S, Caddoux L, Brazier C, Mahéo F, Simon J-C, Micoud A, Roy L (2016) Assessment of the dominance level of the R81T target resistance to two neonicotinoid insecticides in Myzus persicae (Hemiptera: Aphididae). J Econ Entomol. 109: 2182-2189

Mruthunjayaswamy PV, Thiruvengadam J, Sushil Kumar J (2016) Resistance in Maconellicoccus hirsutus (Green) in India to selected insecticides and quantification of detoxifying enzymes imparting resistance. Crop Prot 89:116-122

Nagy C, Cross JV, Markó V (2013) Sugar feeding of the common black ant, Lasius niger (L.), as a possible indirect method for reducing aphid populations on apple by disturbing ant-aphid mutualism. Biol Control 65:24-36. https://doi.org/10.1016/j.biocontrol.2013. 01.005

Nagy C, Cross JV, Markó V (2015) Can artificial nectaries outcompete aphids in ant-aphid mutualism? Applying artificial sugar sources for ants to support better biological control of rosy apple aphid, Dysaphis plantaginea Passerini in apple orchards. Crop Prot 77: 127-138. https://doi.org/10.1016/j.cropro.2015.07.015

Nauen R, Bielza P, Denholm I, Gorman K (2008) Age-specific expression of resistance to a neonicotinoid insecticide in the whitefly Bemisia tabaci. Pest Manag Sci. 64:1106-1110

Nogueira Soares V, da Silva Almeida A, Deuner C, Jauer A, Madruga de Tunes L (2017) Neonicotinoid insecticide treatment improves physiological performance of melon and watermelon seeds. Afr J Agric Res 12:1678-1683

Panini M, Dradi D, Marani G, Butturini A, Mazzoni E (2014) Detecting the presence of target-site resistance to neonicotinoids and pyrethroids in Italian populations of Myzus persicae. Pest Manag Sci. 70:931-938

Pappas ML, Koveos DS (2011) Life-history traits of the predatory lacewing Dichochrysa prasina (Neuroptera: Chrysopidae): temperaturedependent effects when larvae feed on nymphs of Myzus persicae (Hemiptera: Aphididae). Ann Entomol Soc Am. 104:43-49. https:// doi.org/10.1603/AN10036

Pavlova AK, Dahlmann M, Hauck M, Reineke A (2017) Laboratory bioassays with three different substrates to test the efficacy of insecticides against various stages of Drosophila suzukii (Diptera: Drosophilidae). J Insect Sci. 17:8. https://doi.org/10.1093/jisesa/iew100

Penvern S, Bellon S, Fauriel J, Sauphanor B (2010) Peach orchard protection strategies and aphid communities: towards an integrated agroecosystem approach. Crop Prot 29:1148-1156. https://doi.org/ 10.1016/j.cropro.2010.06.010

Pisa LW, Amaral-Rogers V, Belzunces LP, Bonmatin JM, Downs CA, Goulson D, Kreutzweiser DP, Krupke C, Liess M, McField M et al (2015) Effects of neonicotinoids and fipronil on non-target invertebrates. Environ Sci Pollut Res. 22:68-102

Pisa L, Goulson D, Yan EC, Gibbons D, Sánchez-Bayo F, Mitchell E, van der Sluijs J, MacQuarrie C, Giorio C, Long EY, McField M, Bijleveld van Lexmond M, Bonmatin JM (2017) An update of the World Integrated Assessment (WIA) on systemic insecticides. Part 2: impacts on organisms and ecosystems. Environ Sci Pollut Res. https://doi.org/10.1007/s11356-017-0341-3

Polajnar J, Eriksson A, Virant-Doberlet M, Mazzoni V (2016) Mating disruption of a grapevine pest using mechanical vibrations: from laboratory to the field. J Pest Sci. 89:909-921. https://doi.org/10. 1007/s10340-015-0726-3

Ponti L, Ricci C, Veronesi F, Torricelli R (2005) Natural hedges as an element of functional biodiversity in agroecosystems: the case of a central Italy vineyard. Bull Insectol. 58:19-23

Pozzebon A, Ahmad S, Tirello P, Lorenzon M, Duso C (2014) Does pollen availability mitigate the impact of pesticides on generalist predatory mites? BioControl 59:585-596

Pozzebon A, Loeb GM, Duso C (2015a) Role of supplemental foods and habitat structural complexity in persistence and coexistence of generalist predatory mites. Sci Rep. 5:14997. https://doi.org/10.1038/ srep14997

Pozzebon A, Tirello P, Moret R, Pederiva M, Duso C (2015b) A fundamental step in IPM on grapevine: evaluating the side effects of pesticides on predatory mites. Insects $6: 847-857$. https://doi.org/ 10.3390/insects6040847

Prabhaker N, Castle S, Henneberry TJ, Toscano NC (2005) Assessment of cross-resistance potential to neonicotinoid insecticides in Bemisia tabaci (Hemiptera: Aleyrodidae). Bull Entomol Res. 95:535-543

Puinean AM, Foster SP, Oliphant L, Denholm I, Field LM, Millar NS (2010) Amplification of a cytochrome P450 gene is associated with resistance to neonicotinoid insecticides in the aphid Myzus persicae. PLoS Genet. 6:e1000999

Raga A, Sato M (2011) Toxicity of neonicotinoids to Ceratitis capitata and Anastrepha fraterculus (Diptera: Tephritidae). J Plant Protect Res. 51:413-419 
Rahman T, Broughton S (2016) Evaluation of thiacloprid and clothianidin (neonicotinoids) as alternative to fenthion (organophosphate) for control of Mediterranean fruit fly (Diptera: Tephritidae) in deciduous fruit orchards. Crop Prot 90:170-176

Rebach S, French DP (1996) Effects of Dimilin on the blue crab, Callinectes sapidus, in shallow-water habitats. Estuaries 19: 279-287

Reissig WH (2003) Field and laboratory tests of new insecticides against the apple maggot, Rhagoletis pomonella (Walsh) (Diptera: Tephritidae). J Econ Entomol. 96:1463-1472. https://doi.org/10. 1603/0022-0493-96.5.1463

Reyes M, Franck P, Charmillot PJ, Ioriatti C, Olivares J, Pasqualini E, Sauphanor B (2007) Diversity of insecticide resistance mechanisms and spectrum in European populations of the codling moth, Cydia pomonella. Pest Manag Sci. 63:890-902

Ribeiro LP, Akhtar Y, Vendramim JD, Isman MB (2014) Comparative bioactivity of selected seed extracts from Brazilian Annona species and an acetogenin-based commercial bioinsecticide against Trichoplusia ni and Myzus persicae. Crop Prot 62 (Supplement C):100-106

Rieux R, Simon S, Defrance H (1999) Role of hedgerows and ground cover management on arthropod populations in pear orchards. Agric Ecosyst Environ. 73:119-127. https://doi.org/10.1016/S01678809(99)00021-3

Rogers MA, Burkness EC, Hutchison WD (2016) Evaluation of high tunnels for management of Drosophila suzukii in fall-bearing red raspberries: potential for reducing insecticide use. J Pest Sci. 89: 815-821

Romero A, Anderson TD (2016) High levels of resistance in the common bed bug, Cimex lectularius (Hemiptera: Cimicidae), to neonicotinoid insecticides. J Med Entomol. 53:727-731

Saeed R, Razaq M, Abbas N, Jan MT, Naveed M (2017) Toxicity and resistance of the cotton leaf hopper, Amrasca devastans (Distant) to neonicotinoid insecticides in Punjab, Pakistan. Crop Prot 93:143-147

Salis S, Testa C, Roncada P, Armorini S, Rubattu N, Ferrari A, Miniero R, Brambilla G (2017) Occurrence of imidacloprid, carbendazim, and other biocides in Italian house dust: potential relevance for intakes in children and pets. J Environ Sci Health B 52:699-709. https://doi. org/10.1080/03601234.2017.1331675

Santos MF, Santos RL, Tomé HVV, Barbosa WF, Martins GF, Guedes RNC, Oliveira EE (2016) Imidacloprid-mediated effects on survival and fertility of the Neotropical brown stink bug Euschistus heros. J Pest Sci. 89:231-240

Sauge M-H, Grechi I, Poëssel J-L (2010) Nitrogen fertilization effects on Myzus persicae aphid dynamics on peach: vegetative growth allocation or chemical defence? Entomol Exp Appl. 136:123-133. https://doi.org/10.1111/j.1570-7458.2010.01008.x

Sauphanor B, Severac G, Maugin S, Toubon JF, Capowiez Y (2012) Exclusion netting may alter reproduction of the codling moth (Cydia pomonella) and prevent associated fruit damage to apple orchards. Entomol Exp Appl. 145:134-142. https://doi.org/10. $1111 / j .1570-7458.2012 .01320 . x$

Saussure S, Plantegenest M, Thibord J-B, Larruodè P, Poggi S (2015) Management of wireworm damage in maize fields using new, landscape-scale strategies. Agron Sustain Dev. 35:793-802. https://doi.org/10.1007/s13593-014-0279-5

Schmitt A, Bisutti IL, Ladurner E, Benuzzi M, Sauphanor B, Kienzle J, Zingg D, Undorf-Spahn K, Fritsch E, Huber J, Jehle JA (2013) The occurrence and distribution of resistance of codling moth to Cydia pomonella granulovirus in Europe. J Appl Entomol. 137:641-649. https://doi.org/10.1111/jen.12046

Scott JG, Duhig M, Hamlyn J, Norman R (2014) Environmental contributions to autism: explaining the rise in incidence of autistic spectrum disorders. J Environ Immunol Toxicol 1(2):75-79. https:// eprints.qut.edu.au/84191/
Seagraves MP, Lundgren JG (2012) Effects of neonicotinoid seed treatments on soybean aphid and its natural enemies. J Pest Sci. $85: 125-132$

Sgolastra F, Porrini C, Maini S, Bortolotti L, Medrzycki P, Mutinelli F, Lodesani M (2017) Healthy honey bees and sustainable maize production: why not? Bull Insectol. 70:156-160

Sharon R, Zahavi T, Sokolsky T, Sofer-Arad C, Tomer M, Kedoshim R, Harari AR (2016) Mating disruption method against the vine mealybug, Planococcus ficus: effect of sequential treatment on infested vines. Entomol Exp Appl. 161:65-69

Shawer R, Tonina L, Tirello P, Duso C, Mori N (2018) Laboratory and field trials to identify effective chemical control strategies for integrated management of Drosophila suzukii in European cherry orchards. Crop Prot 103:73-80

Shearer PW, Frecon JL (2002) Managing Brachycaudis persicae (Homoptera: Aphididae) during peach orchard establishment. J Econ Entomol. 95:368-371

Shi X, Jiang L, Wang H, Qiao K, Wang D, Wang K (2011) Toxicities and sublethal effects of seven neonicotinoid insecticides on survival, growth and reproduction of imidacloprid-resistant cotton aphid, Aphis gossypii. Pest Manag Sci. 67:1528-1533

Simon-Delso N, Amaral-Rogers V, Belzunces L, Bonmatin JM, Chagnon M, Downs C, Furlan L, Gibbons D, Giorio C, Girolami V et al (2015) Systemic insecticides (neonicotinoids and fipronil); trends, uses, mode of action and metabolites. Environ Sci Pollut Res 22:534. https://doi.org/10.1007/s11356-014-3470-y

Solomon MG, Cranham JE, Easterbrook MA, Fitzgerald JD (1989) Control of the pear psyllid, Cacopsylla pyricola, in south east England by predators and pesticides. Crop Prot 8:197-205. https:// doi.org/10.1016/0261-2194(89)90027-6

Solomon MG, Cross JV, Fitzgerald JD, Campbell CAM, Jolly RL, Olszak RW, Niemczyk E, Vogt H (2000) Biocontrol of pests of apples and pears in northern and central Europe-3. Predators. Biocontrol Sci Technol. 10:91-128. https://doi.org/10.1080/09583150029260

Souliotis C, Moschos T (2008) Effectiveness of some pesticides against Cacopsylla pyricola and impact on its predator Anthocoris nemoralis in pear-orchards Bull. Insectol. 61:25-30

Spangenberg JH, Douguet JM, Settele J, Heong KL (2015) Escaping the lock-in of continuous insecticide spraying in rice: developing an integrated ecological and socio-political DPSIR analysis. Ecol Model. 295:188-195

Stenberg JA (2017) A conceptual framework for integrated pest management. Trends Plant Sci. 22:759-769

Szendrei Z, Grafius E, Byrne A, Ziegler A (2012) Resistance to neonicotinoid insecticides in field populations of the Colorado potato beetle (Coleoptera: Chrysomelidae). Pest Manag Sci. 68: 941-946

Tacoli F, Pavan F, Cargnus E, Tilatti E, Pozzebon A, Zandigiacomo P (2017) Efficacy and mode of action of kaolin in the control of Empoasca vitis and Zygina rhamni (Hemiptera: Cicadellidae) in Vineyards. J Econ Entomol. 110:1164-1178

Tamindžić G, Nikolić Z, Milošević D, Ignjatov M (2016) Field \& vegetable crops research. Ratarstvo i povrtarstvo 53:90-95

Thany SH (2010) Neonicotinoid insecticides. Historical evolution and resistance mechanisms. Adv. Exp Med Biol. 683:75-83

Tirello P, Pozzebon A, Duso C (2013) The effect of insecticides on the non-target predatory mite Kampimodromus aberrans: laboratory studies. Chemosphere 93:1139-1144

Tiwari S, Mann RS, Rogers ME, Stelinski LL (2011) Insecticide resistance in field populations of Asian citrus psyllid in Florida. Pest Manag Sci. 67:1258-1268

Toda S, Hirata K, Yamamoto A, Matsuura A (2017) Molecular diagnostics of the R81T mutation on the D-loop region of the $\beta 1$ subunit of the nicotinic acetylcholine receptor gene conferring resistance to neonicotinoids in the cotton aphid, Aphis gossypii (Hemiptera: Aphididae). Appl Entomol Zool. 52:147-151 
Trimble RM (1993) Efficacy of mating disruption for controlling the grape berry moth, Endopiza viteana (Clemens) (Lepidoptera: Tortricidae), a case study over three consecutive growing seasons. Can Entomol. 125:1-9. https://doi.org/10.4039/Ent1251-1

Unruh TR, Lacey LA (2001) Control of codling moth, Cydia pomonella (Lepidoptera: Tortricidae), with Steinernema carpocapsae: effects of supplemental wetting and pupation site on infection rate. Biol Control 20:48-56. https://doi.org/10.1006/bcon.2000.0873

van der Sluijs JP, Amaral-Rogers V, Belzunces LP, Bijleveld van Lexmond M, Bonmatin JM, Chagnon M, Downs CA, Furlan L, Gibbons DW, Giorio C et al (2015) Conclusions of the Worldwide Integrated Assessment on the risks of neonicotinoids and fipronil to biodiversity and ecosystem functioning. Environ Sci Pollut Res 22: $148-154$

Van Timmeren S, Wise JC, VanderVoort C, Isaacs R (2011) Comparison of foliar and soil formulations of neonicotinoid insecticides for control of potato leafhopper, Empoasca fabae (Homoptera: Cicadellidae), in wine grapes. Pest Manag Sci. 67:560-567

Vassiliou VA (2011) Effectiveness of insecticides in controlling the first and second generations of the Lobesia botrana (Lepidoptera: Tortricidae) in table grapes. J Econ Entomol. 104:580-585. https:// doi.org/10.1603/EC10343

Voudouris CC, Kati AN, Sadikoglou E, Williamson M, Skouras PJ, Dimotsiou O, Georgiou S, Fenton B, Skavdis G, Margaritopoulos JT (2016) Insecticide resistance status of Myzus persicae in Greece: long-term surveys and new diagnostics for resistance mechanisms. Pest Manag Sci. 72:671-683

Vrancken K, Trekels H, Thys T, Beliën T, Bylemans D, Demaeght P, Van Leeuwen T, De Clercq P (2015) The presence of beneficial arthropods in organic versus IPM pear orchards and their ability to predate pear suckers (Cacopsylla pyri). Acta Hortic. 1094:427-429. https:// doi.org/10.17660/ActaHortic.2015.1094.55

Wallingford AK, Fuchs MF, Martinson T, Hesler S, Loeb GM (2015) Slowing the spread of grapevine leafroll-associated viruses in commercial vineyards with insecticide control of the vector, Pseudococcus maritimus (hemiptera: pseudococcidae). J Insect Sci. 15:112. https://doi.org/10.1093/jisesa/iev094

Walton VM, Daane KM, Bentley WJ, Millar JG, Larsen TE, MalakarKuenen R (2006) Pheromone-based mating disruption of Planococcus ficus (Hemiptera: Pseudococcidae) in California vineyards. J Econ Entomol 99:1280-1290. https://doi.org/10.1093/ jisesa/ieu006

Walton VM, Daane KM, Addison P (2012) Biological control of arthropods and its application in vineyards. In: Bostanian NJ, Vincent C, Isaacs R (eds) Arthropod Management in Vineyards: Pests, Approaches, and Future Directions. Springer, Netherlands, pp 91-117

Wan N-F, Ji X-Y, Gu X-J, Jiang J-X, Wu J-H, Li B (2014) Ecological engineering of ground cover vegetation promotes biocontrol services in peach orchards. Ecol. Eng. 64:62-65. https://doi.org/10. 1016/j.ecoleng.2013.12.033

Wang ZH, Gong YJ, Jin GH, Li BY, Chen JC, Kang ZJ, Zhu L, Gao YL, Reitz S, Wei SJ (2016a) Field-evolved resistance to insecticides in the invasive western flower thrips Frankliniella occidentalis (Pergande) (Thysanoptera: Thripidae) in China. Pest Manag Sci. 72:1440-1444

Wang NX, Watso GB, Loso MR, Sparks TC (2016b) Molecular modeling of sulfoxaflor and neonicotinoid binding in insect nicotinic acetylcholine receptors: impact of the Myzus $\beta 1$ R81T mutation. Pest Manag Sci. 72:1467-1474

Wang X, Anadón A, Qinghua W, Qiao F, Ares I, Martínez-Larrañaga MR, Yuan Z, Martínez M-A (2018)Mechanism of neonicotinoid toxicity: Impact on oxidative stress and metabolism. Annu Rev Pharmacol Toxicol 58:(1):471-507. https://doi.org/10.1146/ annurev-pharmtox-010617-052429. Assessed 9 Oct 2017

Wei Q, Mu XC, Yu HY, Niu CD, Wang LX, Zheng C, Chen Z, Gao CF (2017) Susceptibility of Empoasca vitis (Hemiptera: Cicadellidae) populations from the main tea-growing regions of China to thirteen insecticides. Crop Prot 96:204-210

Wilson H, Miles AF, Daane KM, Altieri MA (2015) Vineyard proximity to riparian habitat influences Western grape leafhopper (Erythroneura elegantula Osborn) populations. Agric Ecosyst Environ. 211:43-50. https://doi.org/10.1016/j.agee.2015.04.021

Wise JC, Vanderpoppen R, Vandervoort C, O’Donnell C, Isaacs R (2015) Curative activity contributes to control of spotted-wing drosophila (Diptera: Drosophilidae) and blueberry maggot (Diptera: Tephritidae) in highbush blueberry. Can Entomol. 147:109-117

Witzgall P, Stelinski L, Gut L, Thomson D (2008) Codling moth management and chemical ecology. Annu Rev Entomol. 53:503-522. https://doi.org/10.1146/annurev.ento.53.103106.093323

Wu G, Jiang S, Miyata T (2004) Effects of synergists on toxicity of six insecticides in parasitoid Diaeretiella rapae (Hymenoptera: Aphidiidae). J Econ Entomol. 97:2057-2066

Wu G, Miyata T, Kang CY, Xie LH (2007) Insecticide toxicity and synergism by enzyme inhibitors in 18 species of pest insect and natural enemies in crucifer vegetable crops. Pest Manag Sci 63:500-510

Yang XQ, Wu ZW, Zhang YL, Barros-Parada W (2016) Toxicity of six insecticides on codling moth (Lepidoptera: Tortricidae) and effect on expression of detoxification genes. J Econ Entomol 109:320-326

Yuan L, Wang S, Zhou J, Du Y, Zhang Y, Wang J (2012) Status of insecticide resistance and associated mutations in Q-biotype of whitefly, Bemisia tabaci, from eastern China. Crop Prot 31:67-71

Zanolli P, Pavan F (2011) Autumnal emergence of Anagrus wasps, egg parasitoids of Empoasca vitis, from grapevine leaves and their migration towards brambles. Agric Forest Entomol 13:423-433. https://doi.org/10.1111/j.1461-9563.2011.00546.x

Žežlina I, Škvarč A, Bohinc T, Trdan S (2013) Testing the efficacy of single applications of five insecticides against Scaphoideus titanus on common grapevines. Int J Pest Manag 59:1-9

Zhang X, Liu X, Zhu F, Li J, You H, Lu P (2014) Field evolution of insecticide resistance in the brown planthopper (Nilaparvata lugens Stal) in China. Crop Prot 58:61-66

Zhao GY, Liu W, Brown JM, Knowles CO (1995) Insecticide resistance in-field and laboratory strains of western flower thrips (Thysanoptera, Thripidae). J Econ Entomol 88:1164-1170 